\title{
Um cartógrafo rebelde? José Joaquim da Rocha e a cartografia de Minas Gerais
}

\begin{abstract}
Júnia Ferreira Furtado ${ }^{1}$
RESUMO: Em 1789, foram descobertos os planos da Inconfidência que abalou a capitania de Minas Gerais, centro de produção aurífera do império português. José Joaquim da Rocha, cartógrafo e militar português, um dos suspeitos de tomar parte neles, foi acusado por alguns dos réus de ter fornecido seus mapas para subsidiar o levante. Apesar de declarar-se inocente, a análise de cinco mapas da capitania, feitos por ele, revelam ter o espaço colonial uma conformação geográfica que ameaçava as ligações de dependência entre a colônia e metrópole.

PALAVRAS-CHAVE: Cartografia. José Joaquim da Rocha. Minas Gerais. História da Cartografia. Brasil Colônia. Inconfidência Mineira.

ABSTRACT: In 1789, the plans of a conspiracy to create an independent nation - known as Inconfidência Mineira - were disclosed and shook the Captaincy of Minas Gerais, which was the center of gold mining activity under the Portuguese Empire. José Joaquim da Rocha, a cartographer and member of the Portuguese armed forces, was suspected of taking part in the plot following accusations by some of the defendants that he had supplied maps of his own authorship to support the uprising. Notwithstanding his pleas of innocence, our analysis of five of his maps of that captaincy revealed that the geographic conformation of the colonial territory threatened the relationship of dependency between the colony and the metropolis.

KEYWORDS: Cartography. José Joaquim da Rocha. Minas Gerais. History of cartography. Brazil as a colony. Inconfidência Mineira.
\end{abstract}

José Joaquim da Rocha foi um engenheiro militar português que serviu no Brasil na segunda metade do século XVIII. Durante sua estada em Minas Gerais, escreveu três importantes Memórias Históricas sobre a capitania, e também ficou conhecido por sua pujante produção cartográfica. Entre seus mapas, destacam-se cinco, todos datados de 1778, um que corresponde a Minas Gerais (Figura 1) e quatro outros que tratam cada um das comarcas de que se compunha a capitania: Rio das Mortes, Sabará (Rio das Velhas), Vila Rica (Ouro Preto) e Serro do Frio (Figuras 2-5). A partir de um exame apenas superficial dessas cartas,

\begin{abstract}
1. Professora Titular do Departamento de História da Universidade Federal de Minas Gerais. Este artigo foi escrito com apoio da Bolsa de Produtividade em Pesquisa CNPq e do Programa Pesquisador Mineiro/FAPEMIG, tendo sido proferido inicialmente como aula magna no concurso de Professor Titular em História Moderna junto ao Departamento de História da Universidade Federal de Minas Gerais, em novembro de 2009. E-mail: <juniaf@ ufmg.br>.
\end{abstract}




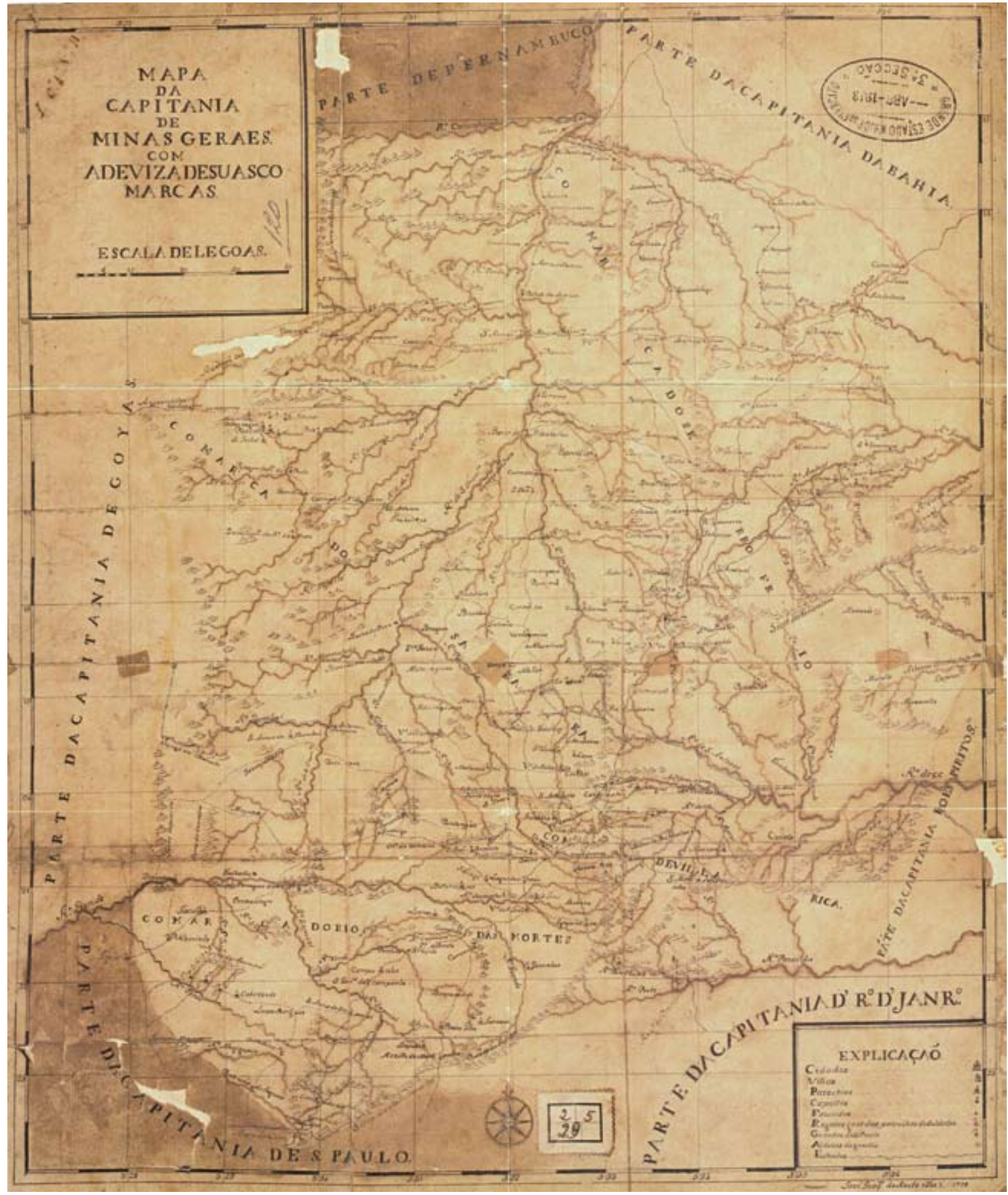

Figura 1 - José Joaquim da Rocha. Mapa da Capitania de Minas Gerais. 1778. Acervo do Arquivo do Exército, Rio de Janeiro. Reprodução de Tibério França. 


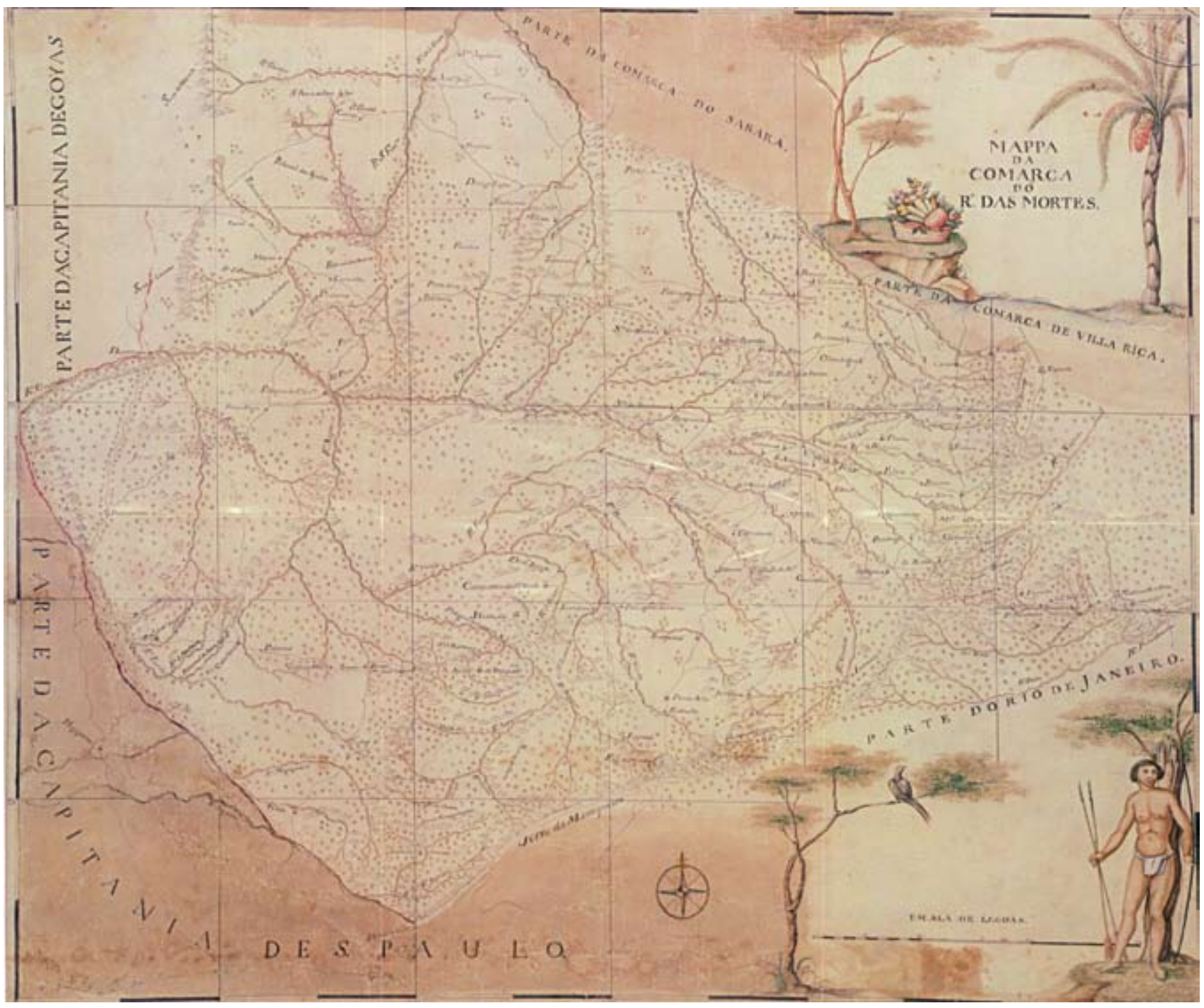

Figura 2 - José Joaquim da Rocha. Mapa da Comarca do Rio das Mortes. 1778. Acervo do Arquivo do Exército, Rio de Janeiro. Reprodução de Tiberio França. 


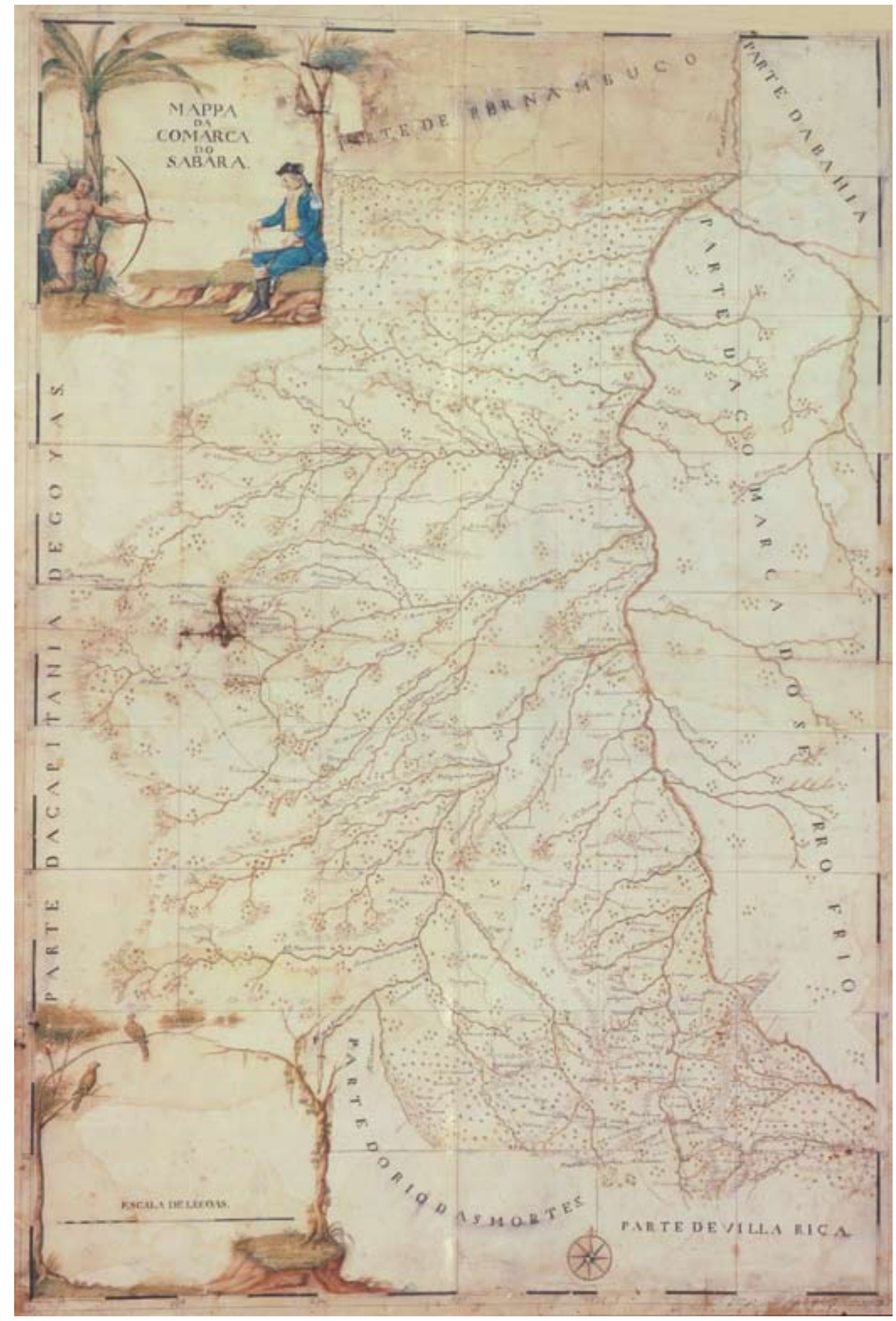

Figura 3 - José Joaquim da Rocha. Mapa da Comarca de Sabará. 1778. Acervo do Arquivo Público Mineiro, Belo Horiozonte. Reprodução de Tiberio França. 


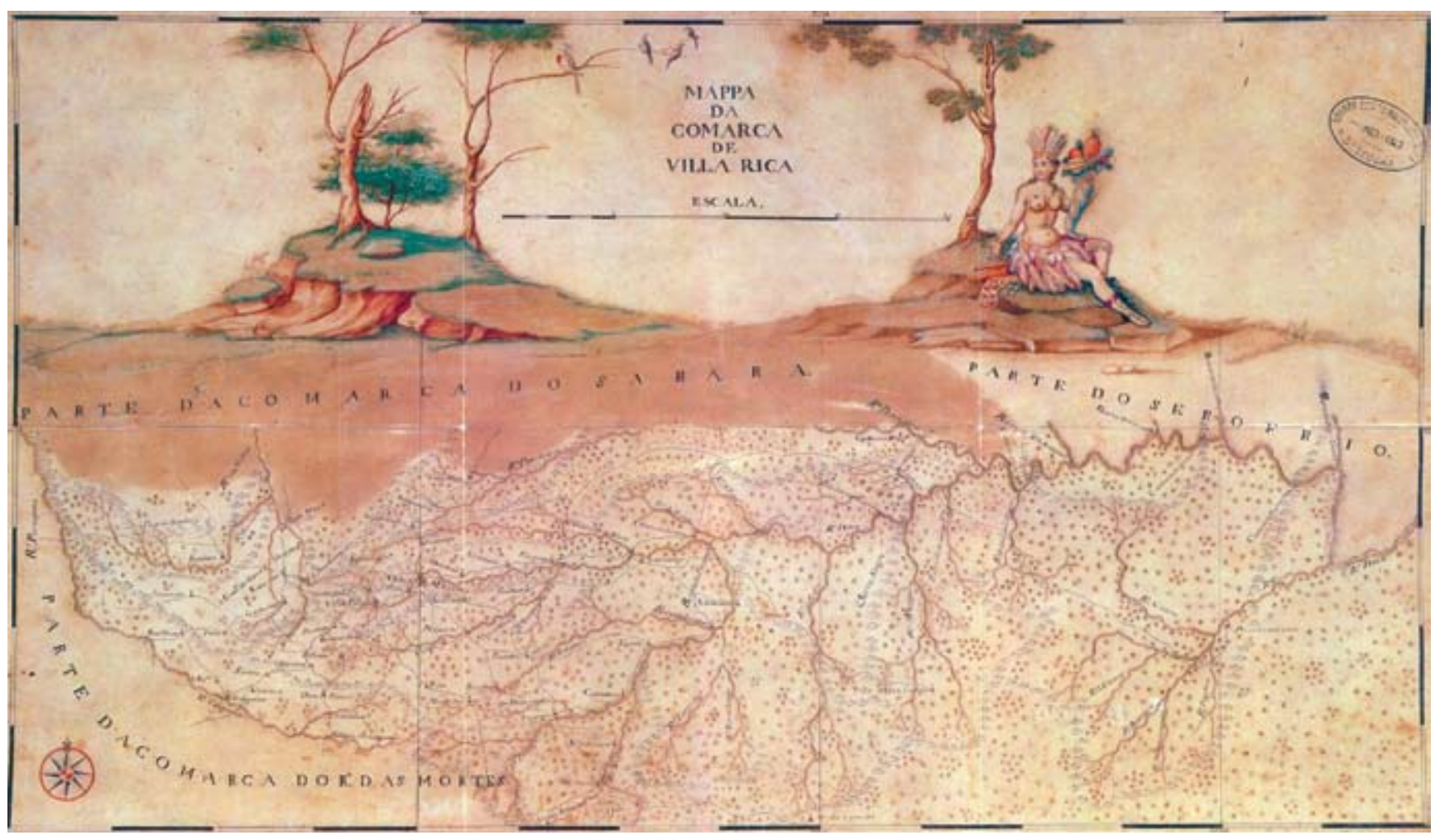

Figura 4 - José Joaquim da Rocha. Mapa da comarca de Vila Rica. 1778. Acervo do Arquivo do Exército, Rio de Janeiro. Reprodução de Tiberio França. 


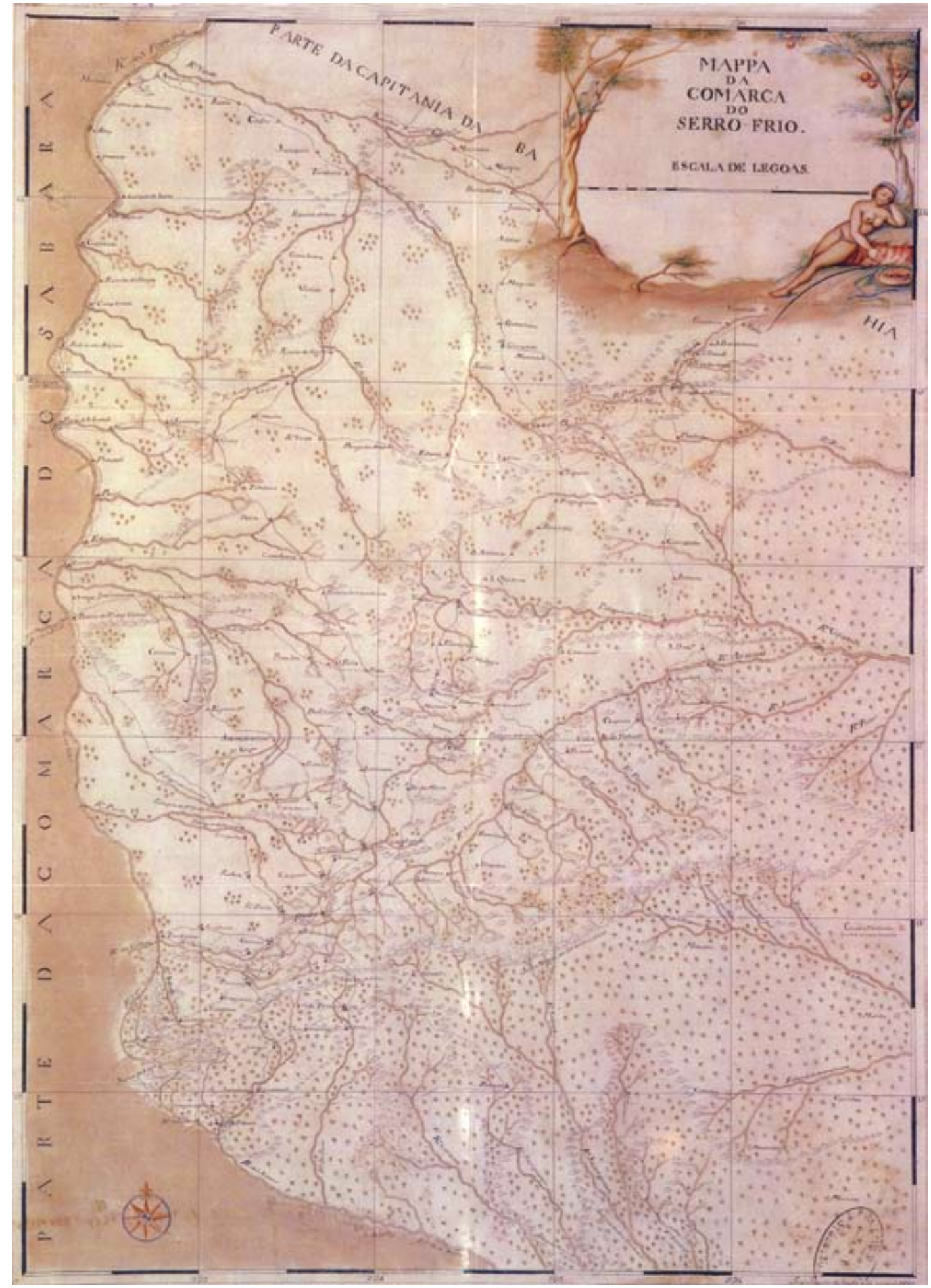

Figura 5 - José Joaquim da Rocha. Mapa da Comarca do Serro do Frio. 1778. Acervo do Arquivo do Exército, Rio de Janeiro. Reprodução de Tiberio França. 
a primeira observação que salta aos olhos é estar José Joaquim da Rocha preparado para empregar, em sua produção, as técnicas mais modernas: os mapas apresentam várias convenções geográficas esquemáticas, apregoam normas que vinham se universalizando, e buscam apresentar uma perfeita correspondência e simetria com a região representada. Se os estudiosos da cartografia de José Joaquim da Rocha têm se atido mais à impressionante qualidade técnica de sua produção, é possível encontrar nos mapas outros níveis de informação. Quando lidas em conjunto com sua produção memorialística, essas cinco representações cartográficas da capitania, de 1778, com as belas iluminuras que as adornam, permitem outras leituras e revelam indícios das concepções políticas do cartógrafo.

\section{inconfidente}

José Joaquim da Rocha, filho do capitão Luís da Rocha e de dona Maria do Planto, nasceu por volta de 1740, em São Miguel da Vila de Souza, ao sul de Aveiro, no Bispado da Extremadura². Sobre sua vida enquanto esteve em Portugal, pouco se sabe. Chegou às Minas Gerais quando Luís Diogo Lobo da Silva era governador (1763-1768), e aí ficou até morrer (1804), tendo permanecido solteiro. Quando da Inconfidência Mineira, residia em Vila Rica e, apesar de ter declarado junto aos Autos da Devassa que vivia de seus negócios, ele também fizera carreira militar e servira no Regimento de Cavalaria - os famosos dragões. Em 1778, alcançou a patente de cabo-de-esquadra ${ }^{3}$, quando então se desligou do serviço militar nas tropas regulares. Até essa época, como engenheiro militar, trabalhara em vários planos para fortificar pontos-chave da capitania ${ }^{4}$.

No dia 15 de abril de 1789, três dias depois de Joaquim Silvério dos Reis, coronel-comandante do Regimento de Cavalaria Auxiliar de Borda do Campo, apresentar ao governador sua denúncia sobre a preparação da Inconfidência Mineira, era protocolada em Vila Rica uma carta-denúncia endereçada ao visconde de Barbacena ${ }^{5}$. Nela, um dos implicados, o tenente-coronel Basílio de Brito Malheiro do Lago relatava o que sabia sobre os planos do levante 6 . Entre os vários incidentes aí descritos, relativos à preparação do movimento, contou do envolvimento do então sargento-mor José Joaquim da Rocha. Disse Basílio de Brito Malheiro do Lago que, estando várias vezes na casa do sargento-mor, em diferentes ocasiões, presenciara discursos em favor da rebelião, proferidos pelo alferes José Joaquim da Silva Xavier, o Tiradentes, pois era grande o descontentamento deste com o governo do visconde de Barbacena. Tais protestos sediciosos, ditos na casa de José Joaquim da Rocha, seriam indícios da conivência e do envolvimento deste último com o levante, já que fora também anfitrião de vários encontros dos inconfidentes ${ }^{7}$. Para piorar a situação do sargento-mor, Basílio de Brito Malheiro do Lago contou, ainda, que ele e vários moradores de Vila Rica viram em poder do Tiradentes um mapa de população ${ }^{8}$
2. Foi ele mesmo quem forneceu estas informações ao prestar depoimento nos Autos de Devassa da Inconfidência Mineira. Disse, em 1789, que tinha 49 anos de idade. Cf. Governo de Minas (v. 4, 1981, p. 115); ver, também, Maria Efigênia Lage de Resende (1995).

3. Na estrutura militar, a patente de cabo-de-esquadra era de condição inferior, mas com estatuto de oficial. Ver o verbete ORGANIZAÇão MILITAR em Adriana Romeiro e Ângela Vianna Botelho (2003, p. 219).

4. Ver Maria Efigênia Lage de Resende (1995, p. 19; 1999).

5. A carta de Basílio de Brito Malheiros constituiu a primeira denúncia escrita sobre o levante, visto que a de Joaquim Silvério dos Reis, apesar de ser datada de 11 de abril, foi escrita posteriormente a esta data, tendo Silvério dos Reis, na ocasião, feito apenas uma denúncia verbal.

6. Sobre o envolvimento de Basílio de Brito Malheiro do Lago nas redes de contrabando de diamantes no Distrito Diamantino e os interesses que o levaram a simpatizar com os planos da Inconfidência Mineira e, depois, delatar os implicados ver Júnia Ferreira Furtado (1996, p. 202, 210-211).

7. Cf. Governo de Minas (v. 1, 1976, p. 96 ; v. 4, 1981, p. 88).

8. Mapa de população: o mesmo que censo. 
9. Cf. Governo de Minas (v. 1, 1976, p. 103).

10. Idem, ibidem.

11. Idem, v. 4, 1981, p. 116.

12. Idem, p. 116-117. José Joaquim da Rocha contou que, tendo emprestado o mapa a alguém de quem não se lembrava, ao recebê-lo de volta, na ponte de São José, passava por ali o alferes que perguntou do que se tratava e, por sua vez, pediu-lhe emprestado o mapa, o que ele fez sem malícia.

13. Idem, v. 7, 1982, p. 205. "Também se obrigou o dito réu a convidar para a sublevação a todas as pessoas que pudesse $[. .$.$] cuja fidelidade$ pretendeu corromper, $[\ldots]$ como foi a Antônio da Fonseca Pestana, a José Joaquim da Rocha." de toda a capitania, obtido com Joaquim José da Rocha, que, inclusive, era o autor do documento9. O mapa configurava uma informação estratégica vital para - planejamento do levante, pois informava em detalhes a disposição do povoamento das Minas Gerais, cuja população, de acordo com o mesmo documento, "era perto de 400 mil pessoas, divididas pelas suas respectivas classes, brancos, pardos e negros, machos e fêmeas" 10 .

Com astúcia, José Joaquim da Rocha procurou esquivar-se das suspeitas que recaíam sobre ele. De início, argumentou que Tiradentes efetivamente poderia ter falado do movimento rebelde enquanto estivera em sua casa, para visitar um amigo ali hospedado, de nome Manoel Antônio de Morais, morador do Serro do Frio, mas que ele não estivera presente a essas conversações. Disse ainda que, nas conversas estabelecidas entre eles em que esteve de fato presente, não se tocara no assunto do levante, e que as que assistira tinham tratado apenas das negociações para a venda de uma lavra que Tiradentes possuía ${ }^{11}$. Quanto ao mapa da capitania, admitiu tê-lo dado ao alferes, porém argumentou que o dera de forma fortuita e "sem malícia alguma, sem entender que ele pudesse servir para coisa alguma"12. Era certamente um artifício de retórica, pois Rocha sabia quão estratégicas e vitais eram as informações contidas em mapas de população, seguidamente mantidos como secretos pelas autoridades portuguesas. Não se pode esquecer, também, que a questão da taxação era vital para a efetivação dos planos dos rebeldes, e que a decretação da Derrama - cobrança dos quintos em atraso - seria utilizada como mola propulsora para levantar toda a capitania e que, de posse de tal mapa, era possível fazer uma estimativa de como esses impostos incidiam sobre as diferentes regiões da capitania. Em prol de sua defesa, José Joaquim da Rocha não chegou a utilizar o argumento de que, ao emprestar o mapa ao alferes, estaria compartilhando tais informações com outro militar, o que talvez diminuísse as suspeitas sobre seu ato. Apesar de ter a sentença proferida contra Tiradentes deixado claro que as autoridades não tinham dúvidas de que, pelas conversas em sua casa, José Joaquim da Rocha estava a par do levante ${ }^{13}$, ele não chegou a ser indiciado como réu. Lembre-se de que o simples conhecimento de um movimento sedicioso era o bastante para incorrer o indivíduo no crime de inconfidência. É, portanto, no mínimo paradoxal que, apesar de a sentença se referir ao fato de ele ter conhecimento do levante, José Joaquim da Rocha não ter sido denunciado nem indiciado como réu pelas autoridades.

Entre as tantas evasivas arroladas por ele, seria possível saber o seu real envolvimento no levante, mesmo não tendo saído implicado ao seu término? Quais seriam suas posições políticas? Tratava-se de um súdito fiel (como argumentara em sua defesa) ou um rebelde político? Onde poderiam ser buscados os indícios de sua participação na rebelião que vinha sendo planejada para eclodir em Minas Gerais? Afinal, quem ele era e quais os significados de seu envolvimento na Inconfidência Mineira? De que maneira sua produção cartográfica pode revelar pistas sobre a suspeita de sedição que nele recaía? 
Durante sua estada em Minas Gerais, José Joaquim da Rocha escreveu três importantes memórias históricas sobre a capitania ${ }^{14}$. A primeira delas, intitulada Geografia Histórica da Capitania de Minas Gerais (c. 1778-1780), foi dedicada a Dom Rodrigo José de Meneses, novo governador da capitania, recém-empossado (1780)15. Na dedicatória, Rocha informa ter reunido na Memória todas as informações que poderiam ser úteis ao governador no desempenho de seu posto. Era tradicional, no mundo luso-brasileiro, dedicar esse tipo de produção memorialística às autoridades - prática corriqueira também no contexto do lluminismo do início dos setecentos, onde, em troca de saber, procurava-se barganhar mercês e honras. Afinal, se saber é poder e, como tal, é instrumento de estado, o produtor desse saber deveria ser recompensado com vantagens honoríficas e, também, recompensas pecuniárias.

Como era esperado, Dom Rodrigo retribuiu o zelo do fiel funcionário. Porém, a mercê recebida como gratificação pelas preciosas informações descritas na primeira memória deve ter satisfeito apenas parcialmente as expectativas de José Joaquim da Rocha. Em 1782, foi the concedida a patente de "sargento-mor das ordenanças dos distritos das capelas de São Luís da Conquista e Santo Antônio da Barra, do termo da vila de Nossa Senhora do Bom Sucesso das Minas Novas do Araçuaí" 16. Era, antes de mais nada, uma patente de caráter honorífico, pois tal função não era remunerada. Porém, como os nomes dos agraciados eram escolhidos apenas entre os principais das vilas, o ganho era simbólico e realizava-se na esfera social, pois distinguia uns em detrimento de outros. Em Cuiabá, por exemplo, o governador Rodrigo César de Meneses recomendou que os oficiais de ordenança "de alferes para cima, inclusive, serão homens dos principais das terras, de melhor consciência, e os mais ricos" ${ }^{\prime 7}$. As companhias de ordenanças constituíam força auxiliar às tropas regulares e, em geral, congregavam homens que não possuíam instrução militar sistemática, apesar de desempenharem, entre outras funções, atividades dessa natureza. Foi comum, nas Minas, que esse tipo de patente fosse concedida a indivíduos ligados às artes músicos, escultores e pintores ${ }^{18}$. Tal era o caso de José Joaquim da Rocha, cujas atividades de cartógrafo e memorialista podem ser inscritas nesse universo, mas que, como já foi dito, era também militar de carreira.

A segunda memória - desta feita nomeada Geografia: a descrição geográfica, topográfica, histórica e política da capitania das Minas Gerais - foi finalizada em 1783 e trata-se de um texto que, salvo apenas algumas pequenas modificações, era quase idêntico ao primeiro. Seguindo a política anterior, a memória era dedicada ao novo governador da capitania, Dom Luís da Cunha Meneses, e contava com uma seção adicional, numa linguagem laudatória, descrevendo a administração de Dom Rodrigo José de Meneses.

Já o terceiro manuscrito, a Memória Histórica da Capitania de Minas Gerais, veio à luz em 1788 e, como esperado, era novamente dedicado ao novo
14. Para um estudo mais aprofundado da Memorialística de José Joaquim da Rocha, ver Maria Efigênia Lage de Resende (1995, 1999). Em seu levantamento sobre os escritos de José Joaquim da Rocha, a autora encontrou 12 manuscritos e 3 publicações (1995, p. 29).

15. Ver José Joaquim da Rocha (1995).

16. A informação se encontra no Arquivo Público Mineiro, em Belo Horizonte, no Livro de Patentes, f. 926-927. Apud Maria Efigênia Lage de Resende (1995, p. 22)

17. A recomendação do governador está no Registro do regimento e forma q. se hão de governar as ordenanças Apud Otávio Canavarras (2004, p. 129).

18. Ver o verbete PERÍODO COLONIAL, em Adriana Romeiro e Ângela Vianna Botelho (2003, p. 220). 
19. Para demonstrar a utilidade dos textos, o próprio José Joaquim da Rocha afirma, a Marinho de Melo e Castro, que os governadores fizeram bom uso dos textos e que "todas estas obras ou partes delas têm sido remetidas a V. Exa. pelos governadores que tem governado a mesma capitania". Cf. Governo de Minas (v. 5, 1982, p. 48-49). Apud Maria Efigênia Lage de Resende (1995, p. 44).

20. Maria Efigênia Lage de Resende (1999, p. 63-67).

21. Idem, p. 65-66

22. Ver Júnia F. Furtado (2005).

23. Apud Luciano Raposo de Almeida Figueiredo e Maria Verônica Campos (1999, p 203-209).

24. Idem, p. 277 governador da capitania, o visconde de Barbacena. Seguindo a mesma estratégia dos textos anteriores, incluía observações sobre o período governado por Luís da Cunha Meneses e os primeiros meses da administração de Barbacena.

Os três textos guardavam muitas semelhanças e poucas diferenças. Serviam não apenas de panegírico para exaltar as ações dos governadores precedentes, como também para instrumentalizar os recém-empossados nos assuntos da capitania ${ }^{19}$. Assim, continham não só as descrições históricas sobre as Minas Gerais, mas reuniam um conjunto notável de documentos - listas de impostos, mapas de população, tábuas de ofícios, folhas de despesa dos ofícios, folhas eclesiásticas, relação de paróquias, entre outros. As informações estavam sistematizadas por vilas ou comarcas, permitindo, ao governador recém-chegado, uma visão integral das Minas Gerais (ou em partes), o que em muito facilitaria suas futuras ações.

Além de Rocha ter copiado dos anteriores, quase literalmente, nesse texto também se percebem similitudes entre os seus escritos memorialísticos em relação a outros de mesma natureza que já circulavam pela capitania (não podemos nos esquecer que a questão da autoria funcionava segundo critérios diferentes dos atuais). Maria Efigênia Lage de Resende chama a atenção para as semelhanças entre o texto de Rocha e o poema Vila Rica, de autoria de Cláudio Manuel da Costa, em particular o seu preâmbulo intitulado Fundamento Histórico ${ }^{20}$. Essas similitudes, embora ocupem espaço reduzido no conjunto dos escritos de José Joaquim da Rocha, são relevantes em termos de significado; e muito nos informam sobre as questões com que se defrontavam, nas décadas de 1770 e 1780, o autor e parte da elite da capitania, sendo que algumas delas acabam por se revelar também na Inconfidência Mineira. Vejamos.

A primeira semelhança entre os textos (de Rocha e de Cláudio Manuel da Costa) é relativa às descrições acerca da descoberta do ouro e de outras riquezas minerais na capitania de Minas $^{21}$. Era inconteste a atribuição de tais descobertas aos paulistas, porém tal ato não era, até então, exaltado como um feito memorável, a ser enaltecido pelos autores que o descreviam, mas, antes, era resultante da maneira selvagem como os paulistas viviam, tais quais os índios. Assim, quando o ouvidor Caetano Costa Matoso, em meados do século XVIII, recolheu alguns relatos escritos dos antigos moradores das Minas, percebe-se - no conjunto dos textos coevos que descreviam os primeiros tempos da região, seus moradores e seus principais acontecimentos - uma predominância de um discurso emboaba em detrimento de um discurso paulista ${ }^{22}$. Como exemplo, num depoimento anônimo de um morador de Mariana, os paulistas eram acusados de terem "os gênios insolentes" 23, pois tratavam com desprezo os forasteiros. José Álvares de Oliveira, morador da comarca do Rio das Mortes, considerava que paulista era sinônimo de "horrendo, fero, ingente e temeroso". Contou que eles se apoderaram "de todo o descoberto como costumavam em todas as minas, porque em todas punham e dispunham despoticamente pelo ditame de assim 0 quero, assim o mando, e à razão prevalece a vontade!" 24 .

Esse mesmo discurso emboaba pode ser percebido nos relatos do 
médico português José Rodrigues Abreu, um dos primeiros, no Reino, a escrever o que se passou em Minas Gerais na época da guerra dos Emboabas ${ }^{25}$. Para ele, os paulistas eram selvagens, não tinham civilização e nem ao menos produziam o necessário para sua subsistência. Relatou que muitos "ficam sem cultura, ou nas suas povoações, ou metidos no mato, onde andam anos sem mais provimento para sua subsistência que pólvora, munição e machados. Vivem de caça que matam, de palmitos e mel de abelhas que encontram fabricados nos troncos das árvores". Percebe-se, na forma como ele narra o desbravamento das minas, que seu texto é antes uma condenação aos paulistas do que uma exaltação dos seus feitos. Afirmou que era exatamente devido ao fato de viverem como selvagens que eles foram capazes de desbravar a região, pois, distantes da civilização, "com este método têm atravessado os dilatados sertões da América portuguesa, entrando pela banda do sul, em terras de Buenos Aires, e pela do norte, nas do Pará" 26 .

Diametralmente divergente dessa visão, no poema Vila Rica, finalizado em 1773, Cláudio Manuel da Costa se insurge contra o fato de que

os naturais da cidade de São Paulo, que têm merecido a um grande número de geógrafos antigos e modernos serem reputados por uns homens sem sujeição ao seu Soberano, faltos do conhecimento e do respeito que devem às suas leis, são os que nesta América têm dado ao Mundo as maiores provas de obediência, fidelidade e zelo pelo seu Rei, pela sua Pátria e pelo seu Reino ${ }^{27}$.

Na mesma direção, em seus escritos, José Joaquim da Rocha realiza exatamente o que Cláudio Manuel da Costa conclamara alguns anos antes: exalta os feitos dos paulistas. Para ele, Bartolomeu Bueno era "dotado de bastante agilidade e fortaleza de espírito" 28 , Manoel Garcia Velho "era abundante de habilidade e engenho"29, já Fernão Dias Paes Leme não teve "a glória de apresentar ao soberano o testemunho de seu zelo e da sua lealdade", pois foi colhido pela morte ${ }^{30}$. Para o autor, o desbravamento das minas ocorrera porque os paulistas estavam menos interessados na "conquista do índio que na diligência do ouro"31.

Uma segunda e significativa semelhança entre as Memórias, de José Joaquim da Rocha, e o poema Vila Rica, de Cláudio Manuel da Costa, é a forma como ambos interpretam a Guerra dos Emboabas ${ }^{32}$. Novamente se observa a inversão do discurso tradicional, pró-emboaba, para uma visão pró-paulista do conflito. Para José Joaquim da Rocha, o rei tinha garantido aos paulistas, em troca de seus serviços, a posse e o controle da região, o que vinha sendo ameaçado pela invasão de forasteiros, pois "conseguiram os europeus a expulsão e despejo dos paulistas, pelos anos de 1707 até 1710, regendo-os, nesta ação, Manuel Nunes Viana, com caráter de governador" 33 , em total afronta às promessas do rei. Rocha salienta, ainda, o aspecto sedicioso do levante emboaba, pois Nunes Viana, ao invés de ser nomeado governador pelo rei, num cerimonial pleno de significados simbólicos ${ }^{34}$, tinha sido "condecorado" por alguns líderes baianos,
25. VerJúnia F. Furtado (2005).

26. Cf. José Rodrigues Abreu (1733, p. 598).

27. Cláudio Manuel da Costa, apud Dominício Proença Fitho (1996, p. 360).

28. José Joaquim da Rocha (1995, p. 79).

29. Idem, p. 80

30. Idem, p. 83

31. Idem, p. 81.

32. Cf. Maria Efigênia Lage de Resende (1999, p. 63-67).

33. Cf. José Joaquim da Rocha (1995, p. 85).

34. Ver Francisco Carlos Cardoso Cosentino (2005). 
35. Cf. José Joaquim da Rocha (1995, p. 85).

36. Idem, p. 86-87. O autor é o primeiro a registrar o episódio e inaugura a tradição acerca do Capão da Traição, cuja existência até hoje cinde a historiografia sobre a guerra. Afirmação de Maria Efigênia Lage de Resende na n. 21, p. 85, da mesma obra.

37. Idem, p. 87

38. Idem, p. 89.

39. Cláudio Manuel da Costa. Apud Dominício Proença Filho (1996, p. 359). sendo que um deles, invertendo as hierarquias de tais investiduras, era subordinado ao próprio governador e "exercia o posto de mestre-de-campo, por nomeação do mesmo Viana" ${ }^{35}$.

O discurso emboaba tradicional é novamente invertido quando, em seguida, José Joaquim da Rocha atribui, desta feita aos emboabas, o caráter selvagem, qualidade negativa que sempre estivera associada aos paulistas. Tal caráter, segundo o autor, teria se manifestado epicamente no episódio que posteriormente ficou conhecido como o capão da traição, quando o sargento-mor Bento do Amaral, que liderava os emboabas, "passou à espada todos os [paulistas] que lá estavam"36. Desse gênio bárbaro, o autor eximia apenas o líder Manuel Nunes Viana, que foi descrito por ele como alguém que, entre os levantados emboabas, "tinha melhor índole que todos" 37.

Mas a essa positividade do papel dos paulistas nos primeiros tempos das Minas, José Joaquim da Rocha sobrepõe a presença soberana da Coroa portuguesa. É graças a ela que não só se soluciona o conflito, estabelece-se a paz, mas, principalmente, que a ordem e a norma se impõem na região, em particular devido à ação dos governadores. Assim, o governador Antônio de Albuquerque foi retratado como o pacificador da guerra e como "o primeiro que susteve com desembaraço as rédeas do governo: que pisou as Minas com luzimento e firmeza do caráter em que o rei o pusera, que promulgou as leis do soberano e fez respeitar neste continente o seu nome"38. Nesse aspecto, ainda que predomine um discurso pró-paulista, Rocha exalta positivamente o caráter normatizador da presença portuguesa, por meio das autoridades nomeadas pela Coroa, especialmente os governadores, que, nas páginas das Memórias, sucedem-se uns aos outros; e cujos feitos são, em geral, glorificados nas diferentes versões que o texto adquire, revelando o caráter pragmático dos textos.

Mas, antes de mais nada, há um fio condutor que se encontra subjacente às narrativas de Cláudio Manuel da Costa e de José Joaquim da Rocha. E também aproxima os dois textos, ainda que o primeiro lance mão do discurso poético, mais épico no tom, para enfatizar sua mensagem. Assim, em ambas as narrativas - a poética e a histórica -, as Minas configuram-se como um espaço central no interior do império português. Cláudio Manuel da Costa conclama que "estas Minas, pelas riquezas que têm derramado por toda a Europa, e pelo muito que socorrem com a fadiga de seus habitantes ao comércio de todas as nações polidas, eram dignas de alguma lembrança na posteridade" 39 . E o que - poema Vila Rica imortalizava em versos, as Memórias Históricas de Rocha ilustravam em informações e números, imprimindo a estes, inclusive, novos significados. Ao diligente administrador, nas diversas tabelas e mapas (de ofício, de tributos, de rendimentos, entre inúmeras outras), Rocha revelava que a riqueza trazida pela exploração do ouro e dos diamantes, e que emanava da capitania, era tanta, que provocara toda uma reorientação da dinâmica do império português. A enorme população do distrito minerador, possível de ser visualizada em seus domićlios a partir do mapa de população anexo, tornara-se, ao longo do século XVIII, seu centro e seu sustentáculo, que se expressava nos inúmeros 
impostos e taxas que a Coroa arrecadava. (Calcula-se que a produção oficial de ouro nas Minas Gerais totalizou o montante de 650 toneladas; e a de diamantes atingiu a assombrosa cifra de pouco mais de 3 milhões de quilates.) Laura de Mello e Sousa encontrou perspectivas análogas ao analisar o Canto Genetlíaco, poema de Alvarenga Peixoto, escrito em $1782^{40}$. Esse poema também conclama que "a superfície das serras 'brutas' oculta riquezas que pagam as alianças políticas da metrópole"4l.

Como os três autores, Dom Luís da Cunha - diplomata português em várias cortes européias e um dos grandes expoentes da política portuguesa de então -, em sua carta de instruções a Marco Antônio de Azevedo Coutinho (novo secretário dos Negócios Ultramarinos de Portugal), já na primeira metade do século atingira a mesma percepção da centralidade que o Brasil adquiria e profetizara a necessidade da transferência da corte portuguesa para o Rio de Janeiro. Argumentava que "o príncipe, para poder conservar Portugal, necessita totalmente das riquezas do Brasil, e de nenhuma maneira das de Portugal [...] de que se segue que é mais cômodo, e mais seguro, estar onde se tem o que sobeja, [do] que onde se espera o de que se carece" 42 . No entanto, se Cláudio Manuel da Costa e José Joaquim da Rocha não eram os primeiros a enxergar tal fenômeno, eram totalmente novos e diversos entre si não só a maneira como cada um o percebeu como os significados que atribuíram a tal percepção.

Para Dom Luís da Cunha, essa percepção esboçava-se em um projeto geopolítico mais amplo, de soberania do império português sobre a América, em oposição às ambições da Coroa espanhola. Inseria-se na lógica do imperium e advogava apenas o deslocamento de sua centralidade; e, nesse caso, não para as Minas, mas para a América portuguesa - o Brasil. Para Cláudio Manuel da Costa, o centro era o Ribeirão do Carmo (Mariana) - a sua pátria, o seu local de nascimento 43 . "O peso dessa nova dignidade épica e civil [é] conferida a Vila Rica - e por extensão [desta] a toda a capitania"44. Para Alvarenga Peixoto é "a América - no poema quase sempre sinônimo de Minas Gerais", e a criança homenageada nos seus versos era sempre exaltada como americana, e não, brasileira ${ }^{45}$ ou mineira. Já para José Joaquim da Rocha, a centralidade é, desde o primeiro momento, a própria capitania das Minas como um todo. No seu caso, diferentemente de Cláudio Manuel da Costa, não se trata de uma expansão da noção mais corriqueira de pátria, que por essa época era comumente associada ao local de nascimento ${ }^{46}$, uma vez que ele havia nascido no reino ${ }^{47}$. Mas, como salienta Rafael Bluteau em seu dicionário, "muitas vezes sucede, que se toma mais amor a uma terra estranha, que ao lugar do próprio nascimento"48. Nesse caso, a pátria torna-se o "local de escolha de residência e atuação"49. É nesse sentido que a capitania torna-se a pátria de José Joaquim da Rocha. Trata-se da valorização de sua importância estratégica e do desejo de deslocamento do vértice central do império para a região no interior de uma pátria maior, que se confunde com o próprio império sob domínio da monarquia portuguesa.

Percebe-se, dessa maneira, que as Minas se configuram para José Joaquim da Rocha como uma entidade única, em contraposição ao seu entorno:
40. Ver Laura de Mello e Sousa (2006).

41. Idem, p. 413.

42. Cf. Luís da Cunha (2001, p. 371).

43. Ver Sérgio Alcides (2003).

44. .Idem, p. 30

45. Cf. Laura de Mello e Sousa $(2006$, p. 411, 417).

46. "Pátria: a terra, vila, cidade ou reino em que se nasceu." Cf. Rafael Bluteau (v. 6, 1739 , p. 320).

47. Observa-se por exemplo, no caso das Minas Gerais, a permanência do local de nascimento associado ao nome de portugueses emigrados, como Matias Castro Porto (natural do Porto), grande comerciante em Sabará ou o célebre Manuel Nunes Viana.

48. Ver Rafael Bluteau (v. 6, 1739 , p. 320).

49. Cf. Marco Morel (2007, p. 16) 
50. Ver Júnia F. Furtado (2005).

51. Essa valorização e mesmo igualdade valorativa entre os súditos do reino e da América também pode ser percebido no Canto Genetlíaco, de Alvarenga Peixoto. Cf. Laura de Mello e Sousa (2006, p. 411).

52. Cf. Marco Morel (2007, p. 34). as demais capitanias limítrofes. Por isso seus textos intitulam-se geografias ou memórias históricas, pois são ambas as matérias - geografia e história - que conferem uma identidade comum à região, distinguindo-a das demais e impondo novos significados à memória. Nesse caso, entrelaçam-se território, população e riqueza, tornando a capitania única em relação ao restante do império português. São esses três elementos que conferem coesão a Minas e dotam-na de sua alteridade. A capitania se configura, então, a partir da definição de seu espaço, fechado em relação ao restante do Brasil, que guarda uma infinidade de riquezas e é povoado por aqueles que compartilham uma identidade - sua herança paulista, agora glorificada. Eis aí o que sustenta a sua totalidade, conferindo-the alteridade. Nesse sentido, o texto deixa de ser visto apenas como instrumento para os governadores, ou para garantir promoções pessoais, e adquire novos significados, na medida em que à capitania passa a ser atribuída uma centralidade e que, a um pensamento emboaba, começa a opor-se uma visão paulista da conquista.

Diferentemente do que já sugeriram outros autores, esse pensamento pró-paulista não significa o surgimento de uma noção de nativismo, mas deriva da percepção da alteridade e da centralidade dessa região no interior do império português. Essa noção de centralidade inerente às Minas começou a surgir na primeira metade do século XVIII e é anterior ao processo de resgate da contribuição paulista para a abertura da região. Porém, inicialmente, tal percepção se configura no interior de um discurso emboaba, que concebia a região como um lugar destinado por portugueses e para eles ${ }^{50}$. É interessante observar que, ao longo do século, esta centralidade passa a integrar um discurso que procura resgatar o papel dos paulistas, acentuando ainda mais a alteridade da região em relação ao restante do império e valorizando, também, o papel dos súditos de além-mar ${ }^{51}$.

Por essa época, foi o conde de Linhares, Dom Rodrigo de Souza Coutinho, quem percebeu com mais clareza a necessidade de reformas para redefinir, dentro do ideário iluminista, os papéis das diversas partes do império português, cuja coesão natural demandava novas articulações com patamares menos desiguais entre as conquistas e o reino. "Nesse império renovado, haveria dois centros de força, um na Europa e outro na América." 52 . As Minas Gerais, na concepção de muitos moradores da região, por sua pujança mineral, enquanto sustentáculo econômico da monarquia, merecia uma inserção em bases mais favoráveis na balança política do império. José Joaquim da Rocha era uma das vozes que clamava por mudanças.

Assim, não é por caso que há um denominador comum em todas as diferentes versões em que seus textos memorialísticos se apresentam ao longo das décadas de 1770 e 1780: sejam as geografias ou a Memória Histórica, todas tratam da Capitania das Minas Gerais. E, ainda que os textos adquiram uma dinâmica própria em suas diferentes formas, o começo não se altera e o autor sempre inicia com a descrição de sua localização: "Esta capitania está situada na América Meridional, entre $328^{\circ}$ e $336^{\circ}$ de longitude e entre $13^{\circ}$ e $23^{\circ} 27^{\prime \prime}$ 
de latitude; parte ao setentrião com as Capitanias da Bahia e Pernambuco; e ao meio-dia, com as do Rio de Janeiro e São Paulo. Ao levante, com a Capitania do Espírito Santo; e ao ocidente, com a de Goiás"53. $\bigcirc$ que importa aqui não é apenas informar ao leitor a sua localização, mas apresentar a capitania como uma unidade única, cujo território está definido e demarcado, ainda que isso não fosse de todo verdade - e disso bem sabia José Joaquim da Rocha, pois, no desempenho de suas funções como engenheiro militar, percorrera grande parte de sua extensão, principalmente suas áreas limítrofes ${ }^{54}$.

$\bigcirc$ texto que se desenrola a seguir dessa introdução, em suas diversas variantes - o discurso histórico que narra o desbravamento da região e a descoberta dos metais; o relato dos feitos dos governadores; a corografia dos municípios e das comarcas; a descrição dos rios, dos cargos, das patentes e das riquezas locais (pedras, tintas, animais, aves) -, converge linearmente e cronologicamente para dar sustentação a uma entidade maior, o tema central em questão, que é a própria capitania de Minas Gerais.

Mapas da sedição

As mesmas questões que perpassam a produção das Memórias Históricas, de José Joaquim da Rocha, podem ser percebidas a partir da análise da cartografia da capitania produzida pelo autor.

No desempenho da atividade como militar, particularmente como engenheiro responsável pelas edificações militares situadas em pontos-chave da capitania das Minas Gerais, José Joaquim da Rocha percorreu, nela, suas mais diversas partes ${ }^{55}$. Por meio dessas atividades, conheceu profundamente a região, tomando medidas das distâncias entre as diversas localidades, e foi esse conhecimento que the permitiu produzir importantes mapas da área ${ }^{56}$. Inicialmente essa atividade esteve diretamente ligada à sua função militar, mas, depois de ele dar baixa do serviço, a cartografia adquiriu uma dimensão ainda maior e, como a produção das memórias, tornou-se uma atividade autônoma e autorreferente. Assim ele relata que,

servindo a Sua Majestade Fidelíssima vinte e dois anos em praça-de-esquadra, na Europa e nestas Minas, tive a honra de as descrever em Carta Corográfica, por ordem dos Exmos, Generais que as governaram; desde o tempo do governo do Sr. Luís Diogo Lobo da Silva [a] te o do Sr. Antônio de Noronha, que todos me ocuparam neste trabalhoso exercício; e fazendo eu nele um particular estudo, por ser do meu gênio e da minha maior aplicação. ${ }^{57}$

Na cartografia de José Joaquim da Rocha, conhecem-se quatro mapas da capitania como um todo, sendo dois realizados em 1777 e os outros dois em 1778 e 1793, respectivamente. Em 1796, ele produziu um mapa das cabeceiras do julgado do rio das Velhas e, em 1798, um mapa do rio Doce ${ }^{58}$. Dentro de
53. Cf. José Joaquim da Rocha (1995, p. 77)

54. Por exemplo, em 1788, ele produz um mapa da comarca de Vila Rica, onde estabelece o Rio Doce como marco divisor com a capitania do Espírito Santo. E, em 1798, ele risca um Mapa do Rio Doce, onde representa apenas o baixo Rio Doce, próximo à foz, mostrando o desconhecimento da parte média do rio, "sertão povoado de gentio de várias nações", exatamente na porção da divisa entre as duas capitanias. O mapa, pertencente ao acervo da Biblioteca Nacional, está reproduzido em Romeu do Nascimento Teixeira (2002. p. 65).

55. Em correspondência a Martinho de Melo e Castro, informa que se ocupou da "fatura de diferentes [a]petrechos de prevençao para a defesa dessa capitania". Cf. Governo de Minas (v. 5, 1982, p. 48-49).

56. Os mapas então no anexo de Antônio Gilberto Costa et al. (2004, p. 145-151).

57. Cf. José Joaquim da Rocha (1995, p. 74).

58. Sobre estes mapas e suas localizações, ver idem, p. 145; e Romeu do Nascimento Teixeira (2002, p. 65). 
59. Trata-se do Mapa da capitania de Minas Gerais com a divisa de suas comarcas, que faz parte do acervo do Arquivo do Exército, Rio de Janeiro.

60. O de Sabará faz parte do acervo do Arquivo Público Mineiro; e os demais, do Arquivo do Exército, no Rio de Janeiro. Reproduções dos cinco mapas podem ser vistas no anexo a José Joaquim da Rocha (1995).

61. Ele afirma que, em Minas, dedicou-se à "fatura de diferentes [a]petrechos de prevenção para a defesa desta Capitania, na descrição dela em carta corográfica e, ultimamente, em história, com a notícia de seu descobrimento, estabelecimento, rendimento e despesa por ano". Cf. Governo de Minas (v. 5, 1982, p. 48-49). Apud Maria Efigênia Lage de Resende (1995, p. 44)

62. Cf. José Joaquim da Rocha $(1995$, p. 74$)$

63. Ver Beatriz Piccolotto Siqueira Bueno (2003)

64. Idem (2008) sua extensa produção cartográfica, destacam-se os cinco mapas já citados, todos datados de 1778, um que corresponde a toda a capitania ${ }^{59}$ e quatro outros que tratam, cada um, das comarcas de que se compunha a capitania: Rio das Mortes, Sabará (Rio das Velhas), Vila Rica (Ouro Preto) e Serro do Frio60.

O texto introdutório de José Joaquim da Rocha à primeira Geografia Histórica e a carta endereçada a Martinho de Melo e Castrobl são alguns dos indicativos de que essas atividades - a de cartógrafo e a de memorialista estavam inseparavelmente imbricadas. Ambas se desenvolveram de forma concomitante e culminaram no ano de 1778, quando o cabo-de-esquadra deu baixa em sua patente. Foi nesse ano que ele produziu as cinco cartas geográficas citadas e iniciou a redação do texto histórico, como ele mesmo conta:

E sucedendo dar baixa por não ter com que passar no serviço, cuidei logo em dar os últimos fins ao meu trabalho, com o socorro do capitão Francisco Antônio Rebelo, que me ajudou, procurando com o seu respeito, diligência e zelo, todas as notícias que me podiam ser ocultas e ainda recordando-me de muitas que não chegaram à lembrançab2.

A partir de um exame apenas superficial dessas cartas, a primeira observação que salta aos olhos é que José Joaquim da Rocha estava preparado para empregar, na produção de cartas geográficas, as técnicas mais modernas. Percebe-se, então, que ele tinha sido treinado nas recentes transformações ocorridas na arte da cartografia e da geografia, implementadas em Portugal a partir da primeira metade do século XVIII, e que se beneficiou disso.

Estas mudanças, ocorridas principalmente durante o reinado de Dom João V (1713-1750), abrangeram não só uma reorientação no ensino dos engenheiros militares como também a publicação de manuais técnicos para orientá-los na prática da produção de cartas, no sentido de uniformização das técnicas, implementando uma linguagem mais esquemática e universal ${ }^{63}$. Entre os manuais que foram publicados nesse período, destacam-se o Tratado do modo o mais fácil de fazer as cartas geográficas... (1722) e O engenheiro português (1729), ambos de Manoel Azevedo Fortes (Figura 6). Esses manuais pretendiam normatizar as técnicas e as formas de representação do espaço, sugerindo, entre outros tantos temas, a adoção de símbolos geográficos mais esquemáticos e universais, as maneiras apropriadas e os instrumentos adequados para a tomada das medidas dos terrenos, as formas como deveriam ser coloridos os mapas, e como representar de maneira ideal os acidentes geográficos (rios, montanhas, etc.) (64 $^{\text {. }}$

Como militar, em meados do século XVIII, enquanto esteve no reino, Rocha muito provavelmente foi preparado, para o exercício da função de engenheiro, nas classes da Aula Régia de Arquitetura Militar, recebendo formação segundo os novos métodos nas áreas de construção de fortificações, de artilharia militar e da cartografia, o que se espelha claramente nos mapas realizados por ele em 1778. As cinco cartas apresentam várias convenções geográficas esquemáticas, como apregoavam as normas que vinham se universalizando: cada mapa é colorido em tons de sépia, as estradas são tracejadas, o campo aparece 


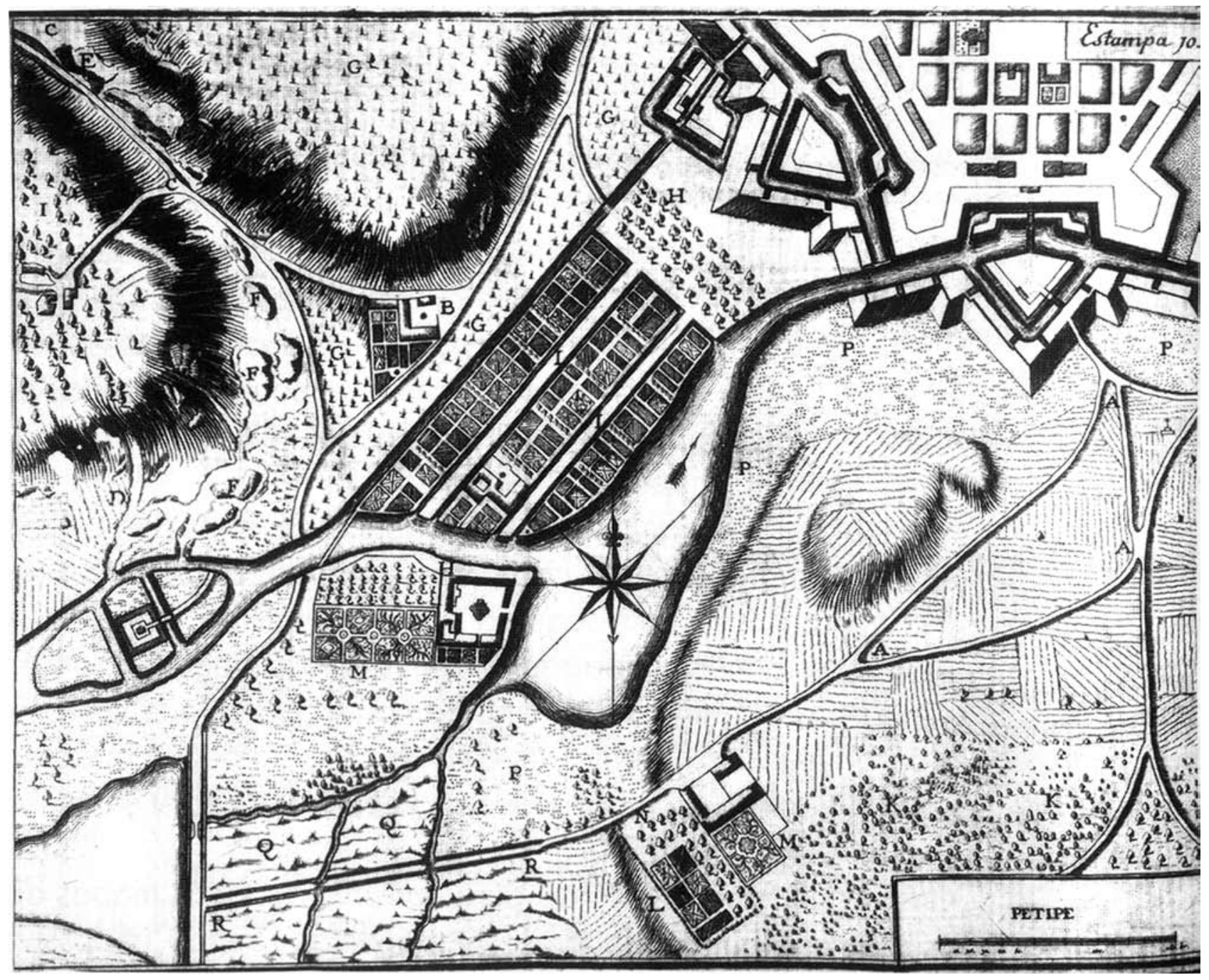

Figura 6 - Manoel Azevedo Fortes. O engenheiro português. Estampa 10. 1728-1729. Acervo da Biblioteca Municipal Mário de Andrade, São Paulo.

coberto por pequenas árvores, os rios são riscados com duas linhas contínuas em paralelo, pequenos montes marcam as serras e as cadeias de montanhas, e o sombreado é feito da esquerda para a direita. Entre tantos outros aspectos, os núcleos urbanos são representados a partir do uso de símbolos mais ou menos complexos, o que espelha a própria hierarquização dos núcleos de povoamento no interior do império português. Isso ocorre, segundo Cláudia Damansceno Fonseca ${ }^{65}$, em paralelismo com a hierarquização da própria estrutura social, pois o enobrecimento das localidades se desenvolvia no interior de um sistema de concessão de títulos, patentes e privilégios, típicos de Antigo Regime, e que, de forma correlata, enobrecia também seus habitantes.
65. Ver Claudia Damasceno Fonseca (2003a; 2003b). 
Mas o mais importante é que as imagens cartográficas buscam apresentar, nesses cinco mapas, uma perfeita correspondência com a região representada. Todas as cidades, as vilas, as estradas, os registros, os rios e os limites da capitania estão razoavelmente dispostos em suas posições no território, e as escalas apresentam uma adequada proporção com o espaço real. Uma escala em léguas, disposta em um dos cantos das cartas, enfatiza ainda mais a perfeita relação entre o território real e a sua representação espacial. Além disso, uma rosa dos ventos indica a posição da capitania e suas subdivisões em relação aos pontos cardeais; e, nas bordas, estão marcadas as graduações dos meridianos e das latitudes onde a região se localiza, estabelecidas a partir do meridiano da itha de Ferro. O quadriculado sobre o qual se sobrepõem as entidades geográficas desenhadas nos mapas sugere que as medidas foram tomadas com base no método de triangulação, bem explicado por Azevedo Fortes.

Mesmo que os estudiosos da cartografia de José Joaquim da Rocha se restrinjam, na maioria das vezes, à impressionante qualidade técnica de sua produção, é possível encontrar nos mapas outros níveis de informação. $\bigcirc$ que José Joaquim da Rocha apresenta em 1778 não são apenas mapas de uma área geográfica e suas subdivisões: o que ele desenha é uma entidade - a capitania das Minas - e suas partes. Esta só pode ser entendida enquanto espaço unitário, cuja integração é resultado de um processo civilizador hierarquizado, engendrado pela colonização portuguesa e tornado possível a partir da expansão paulista. É por isso que tal cartografia não pode ser dissociada das Memórias e só alcança total inteligibilidade quando ambos os documentos são lidos em conjunto, pois o que Rocha produz é uma geografia humana. Não é por caso, como ele mesmo afirma, o fato de ter dado início conjunta e indissociavelmente ao processo de produção cartográfica e memoralística. Assim, também não é por acaso que, no conjunto da produção cartográfica sobre a região ao longo do século XVIII, um dos mapas de 1778 tenha sido o primeiro a desenhar "a capitania de Minas Gerais" de forma unitária, como identidade autônoma e autorreferente, configurada a partir de seus limites externos e suas subdivisões internas.

Apesar de, por todo o século XVIII, a área que compreende a capitania das Minas Gerais ter experimentado uma intensa produção cartográfica, nenhum dos mapas anteriores ao de Rocha representara unicamente e/ou por inteiro somente a capitania. Até então, dela, em sua maioria, as cartas retratavam apenas áreas mais restritas. Já naquelas que abrangeram todo o território das Minas, o foco não estava na capitania, mas em uma área mais ampla, que englobava o seu entorno, muitas vezes sem sequer especificar com clareza seus limites. $O$ primeiro tipo de carta pode ser representado, por exemplo, pela cartografia dos padres matemáticos; e o segundo, pelo Plano da costa, desde Santa Catarina, thé Itha Grande, em que compreende a Campa. de São Paulo e huma parte das Minas Geraes e Goiáz; e mesmo pelo Mapa das Cortes, que representava toda a América portuguesa.

Um dos motivos para a ausência de uma cartografia cujo objetivo fosse representar a capitania como um todo pode ser encontrado no pragmatismo com 
que a prática da matéria era orientada em Portugal. Assim, grande parte das cartas do período foi produzida com uma finalidade muito específica, que em geral exigia a representação de apenas uma porção do território. Muitos mapas tinham por objetivo, por exemplo, dirimir dúvidas da abrangência de uma jurisdição civil ou eclesiástica - e, nesse caso, bastava representar a região em litígio. Outros objetivavam mapear as riquezas minerais e representavam apenas as áreas de exploração, como os rios diamantinos (ou as minas de salitre na divisa com a Bahia). Alguns tinham como objetivo estabelecer uma demarcação, ou uma subdivisão da capitania, como foi o caso da cartografia do Distrito Diamantino. Aparecem, ainda, mapas feitos apenas para registrar a rota de uma expedição, como a viagem que Luís Diogo Lobo da Silva fez de Vila Rica a São João Del Rei; ou as campanhas que o mestre de campo Inácio Correa Pamplona fez para destruir quilombos ${ }^{66}$.

Por seu turno, não se pode compreender como meramente fortuito o fato de Rocha ter escolhido representar o território inteiro da capitania, conferindo-the unidade e alteridade em relação ao restante do território português na América. No mapa das Minas Gerais, Rocha utiliza vários elementos para acentuar e afirmar sua intenção de sublinhar o caráter unitário presente na representação, deixando explícita a imagem das Minas Gerais como uma entidade singular. Assim, observa-se que, em vermelho ou amarelo, ele reforça a linha divisória externa, separando a capitania, com clareza, das que the são limítrofes, como também apresenta, em azul, as divisões internas das comarcas que depois serão representadas separadamente em quatro outras cartas.

Dessa maneira, os elementos que Rocha dispõe nesses mapas - as cidades, as vilas, as fazendas, os registros, as guardas, as estradas etc. - só podem ser entendidos como integrantes de uma unidade geopolítica autônoma, denominada Capitania das Minas Gerais, que se conecta hierarquicamente ao Império Português enquanto uma de suas partes. Todas as informações de interesse da Coroa estão ali dispostas e integradas ao mundo civilizado que, nas Minas, os portugueses construíram a partir das estradas que cruzam o território, interligando-o. Mesmo os acidentes naturais, rios e montanhas só fazem sentido no interior desse espaço humano e, em geral, servem para demarcar os limites ou mesmo as subdivisões internas da capitania.

Como já dito, os núcleos urbanos são representados a partir do uso de símbolos mais ou menos complexos, o que espelha a própria hierarquização, no interior do império português, desses núcleos de povoamento (Figura 7). De acordo com essa concepção hierárquica, as aldeias de gentios são indicadas apenas por um pequeno aglomerado de pontos em vermelho; as fazendas, por um triângulo da mesma cor; já as sedes de capelas, por um círculo (também vermelho), encimado por uma cruz; as paróquias, por um quadrado que envolve um círculo vermelho encimado por uma cruz; as vilas, por uma pequena igreja de torre lateral; e as cidades por um igreja um pouco maior com torre central, os dois últimos símbolos de igrejas [?] envolvendo também um pequeno círculo vermelho central. Por fim, até mesmo os sertões incultos, habitados pelos índios bravios, são
66. Reproduções desses mapas podem ser vistos em Antônio Gilberto Costa et al. (2004). 


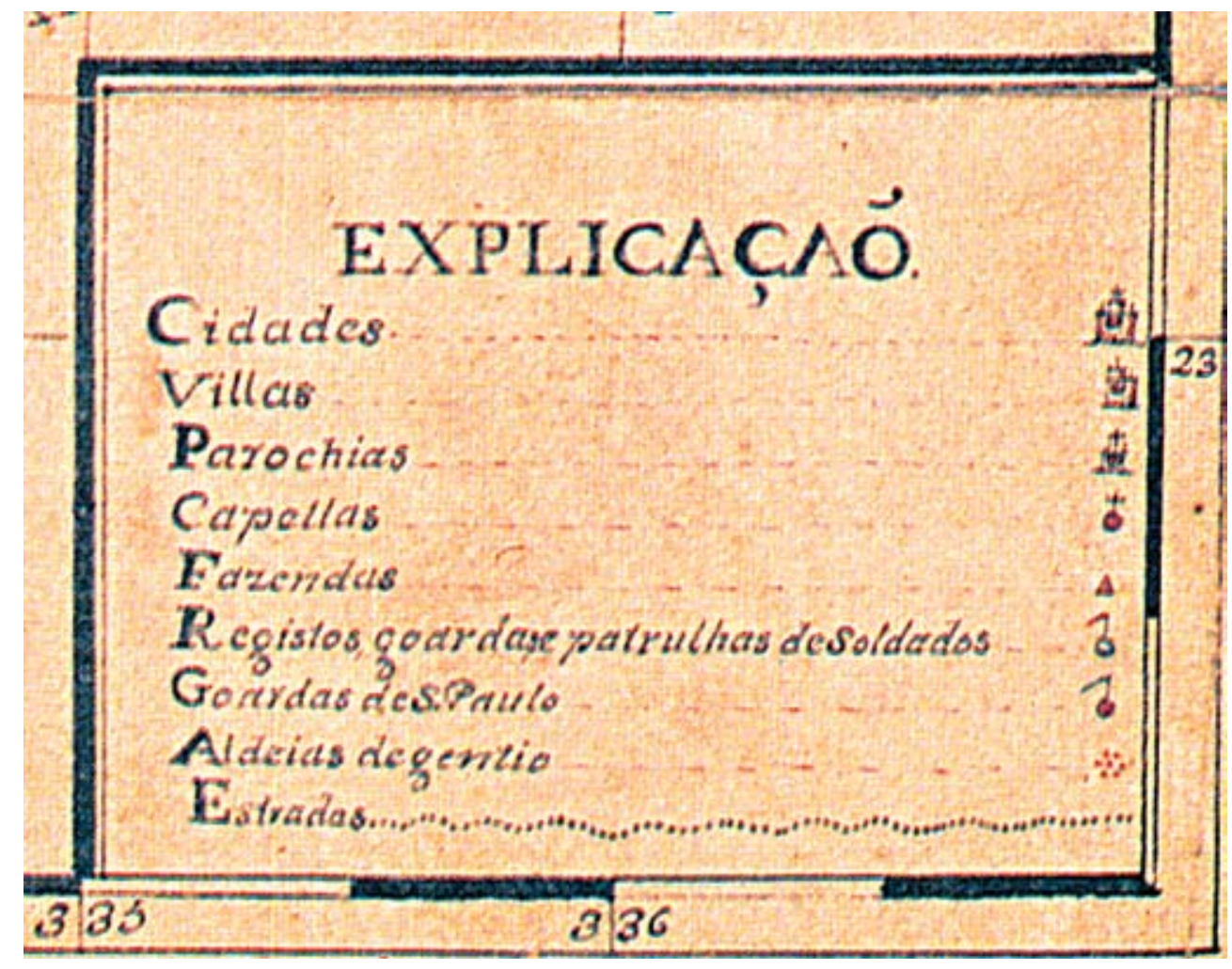

Figura 7 - Legenda do Mapa da Capitania de Minas Gerais. Acervo do Arquivo do Exército, Rio de Janeiro.

hierarquizados aos olhos do cartógrafo. Configurados como espaço de fronteira, exterior à civilização - é verdade -, mas internos à capitania e, por isso, território à espera de ser integrado. Está fora, mas pertence. Nesse espaço estão as aldeias indígenas - que, hierarquicamente, estão abaixo das capelas, das vilas ou das cidades do império português e, por isso, merecem apenas um sinal indicativo fragmentado: pequenos pontos vermelhos, sem a presença da cruz cristã, fator de coesão religiosa e mesmo cultural do império português. Mas, antes de mais nada, são áreas à espera do um processo civilizador desse império e, por isso mesmo, ainda que não compartilhem dos mesmos valores, estão inseridas no universo da representação cartográfica.

Aspecto importante é o fato de o Mapa representando a capitania guardar uma relação com os quatro mapas das comarcas e não ser, apenas, uma reprodução em escala menor da soma dos demais. Assim, há elementos que estão presentes em um e não nos outros, e vice-versa. Por exemplo, examinando-se a região do Serro do Frio (Figura 5), percebe-se que algumas diferenças na maneira como a região é retratada na carta da capitania e na que se refere a esta comarca não se explicam apenas pelas distinções de escala entre as duas. Ao registrar a presença do gentio panhame nas proximidades do rio São Mateus, no 
mapa da comarca, José Joaquim da Rocha acrescenta a informação logo abaixo do topônimo: "que come as mais nações". Nessa mesma carta, um pouco mais ao norte, é representado o rio Piauí, que ostenta apenas o seu topônimo. Mas, na carta da capitania, o nome desse mesmo rio vem acompanhado da seguinte informação: "rio Piaui, onde se tiram as grizalitas (sic.)". Observa-se assim que não é uma mera questão de escala que leva o autor acrescentar ou retirar uma determinada informação. Se assim fosse, as omissões sempre ocorreriam na carta da capitania, onde a escala é de 1:3.000.000, exigindo uma compressão das informações em relação ao da comarca. Analisando as duas ocorrências, observa-se que, na carta da comarca, privilegiou-se a informação etnográfica e, no da capitania, a econômica, que aponta para a importância que a riqueza da capitania adquire para o autor. Tal constatação reforça não apenas o apuro técnico do cartógrafo, como costumam enfatizar, mas também a noção de que, para ele, a representação da capitania enquanto um todo sobrepunha-se ao simples somatório das partes.

As informações que o mapa reunia, quando colocadas nas mãos dos administradores régios, serviam aos intentos da Coroa, instrumentalizando o poder e, por isso mesmo, reforçando-o. Mas, nas mãos dos inconfidentes, podiam adquirir outros significados. Essa dupla e contraditória forma de apropriação desses mapas aponta para as inúmeras possibilidades de leituras e usos que podiam ser conferidos ao mesmo documento e permite, também, que se perceba a pluralidade de significados intrínsecos a eles. Também estavam presentes todas as informações que eram essenciais à preparação do levante: os núcleos urbanos posicionados com precisão, indicando suas distâncias aproximadas; as estradas traçadas, apontando as possíveis ligações entre os diferentes pontos da capitania a serem sublevados, mesmo os mais distantes; as fortificações militares e as guarnições de fronteira registradas de modo que os rebeldes pudessem estar alertas à sua presença.

Elemento importante foi o fato de Rocha ter abandonado o uso do meridiano do Rio de Janeiro como marco orientador dos seus mapas. A partir do início do século XVIII, as nações européias estabeleceram, para suas cartografias, meridianos de referência baseados em pontos nacionais de referência. $\mathrm{Na}$ Europa, a Inglaterra estabeleceu o meridiano de Greenwich; a França, o de Paris; Portugal, o de Lisboa - e o do Rio de Janeiro, na América. A determinação do meridiano do Rio de Janeiro havia sido realizada pelos padres matemáticos em 1730, que usaram essa longitude para orientar sua cartografia ${ }^{67}$. $\bigcirc$ segredo acerca da posição desse meridiano constituiu fator importante para manter o sigilo das reais dimensões e distâncias no interior do território e, por esse motivo, foi utilizado em grande parte da cartografia portuguesa sobre o Brasil até então. Com - objetivo de utilizar uma linguagem mais universal, ferindo de certa forma a política de sigilo adotada pela coroa, Rocha estabeleceu seus mapas a partir do meridiano de Ferro, assim denominado porque utilizava como referência o meridiano que corta esta itha, situada no arquipélago das Canárias ${ }^{68}$.

O meridiano da ilha de Ferro foi empregado pela primeira vez por
67. Ver André Ferrand de Almeida (2001).

68. Cf. Antônio Gilberto Costa et al. (2004, p. 150). 
69. Ver Wilcomb E. Washburn (1987).

70. Ver Martin Bruckner (2006); cf. Gilberto C. Costa et al. (2004, p. 150).

71. Cf. José Joaquim da Rocha (1995, p.169-176).

72. Ver Cristina Ávila e Maria do Carmo Gomes (19901992).

73. Ver Maria Eliza Linhares Borges (2002).
Ptolomeu (século II), e seu uso foi popularizado pelo cartógrafo francês Guillaume Delisle (1675-1726) ${ }^{69}$. Por essa época, esse meridiano começou a ser usado como um meridiano "internacional", na contramão da corrente nacionalista, que cada vez mais, como já foi dito, tendia a empregar meridianos referenciados em suas nações. $\bigcirc$ meridiano de Ferro ocupava um papel emblemático, pois, além do mais, estava a meio caminho entre o velho e novo mundo, estabelecendo a fronteira entre os dois continentes. $\bigcirc$ fato de Rocha empregar o meridiano de Ferro revela-se como um indício intrigante quando se leva em consideração que, devido a este papel simbólico de dividir o novo do velho continente, este meridiano foi utilizado como meridiano de referência na cartografia da nova nação norte-americana após sua independência. Tal escolha não era aleatória. Abandonando o meridiano de Greenwich, que tomava como ponto de referência cartográfica um meridiano posicionado no território da Inglaterra, os cartógrafos norte-americanos buscavam, de forma ostensiva, mostrar a ruptura da jovem nação com a antiga metrópole. Mais tarde, com propósitos nacionalistas, a cartografia norte-americana passou a utilizar o meridiano de Washington ${ }^{70}$. Dessa forma, observa-se que, para além das autoridades portuguesas, Rocha visava a um público mais amplo, uma audiência internacional, incluindo provavelmente os savants relacionados aos movimentos de independência coloniais. Construía um conhecimento cartográfico não submetido aos interesses metropolitanos, inserindo seus mapas numa linguagem universal, e não os destinando apenas ao consumo das autoridades portuguesas, sabidamente hábeis no uso de uma cartografia orientada a partir do meridiano do Rio de Janeiro. E isso configura uma atitude rebelde.

Para Rocha, um aspecto fundamental que conferia coesão à entidade mineira era a riqueza da região, particularmente exposta no capítulo intitulado Do rendimento da Capitania de Minas Gerais ${ }^{71}$. Nessa seção, o autor arrolava uma série de tábuas de rendimentos e despesas que a Coroa auferia nas Minas. Um simples olhar revelava, ao leitor atento, o enorme manancial de riquezas que fluía em direção aos cofres régios. Essa mesma imagem está várias vezes presente nas iluminuras que adornam os mapas de 177872, mostrando que estão intimamente conectadas a leitura dessas imagens e a das informações cartográficas propriamente ditas ${ }^{73}$. No Mapa da Comarca de Vila Rica, uma índia robusta e ricamente vestida segura uma cornucópia de frutas que, desde a antiguidade, era compreendida como símbolo de riqueza (Figura 8). No Mapa da Comarca do Serro do Frio, uma outra índia, desta feita em posição de languidez, mira o fruto da caça realizada sem muito esforço. A seus pés está uma ave abatida e um cesto cheio de mantimentos, nas árvores ao redor abundam frutos e aves silvestres (Figura 9). Finalmente, no Mapa da Comarca do Rio das Mortes, em um canto, está representada uma cesta cheia de frutos e um coqueiro carregado (Figura 10) e, no outro canto, está desenhado um vigoroso selvagem, munido de seu arco e sua flecha (Figura 2). Todas essas imagens convergem para acentuar a riqueza que a natureza da região era naturalmente dotada.

No Mapa da Comarca de Sabará (Figura 3), no canto inferior 

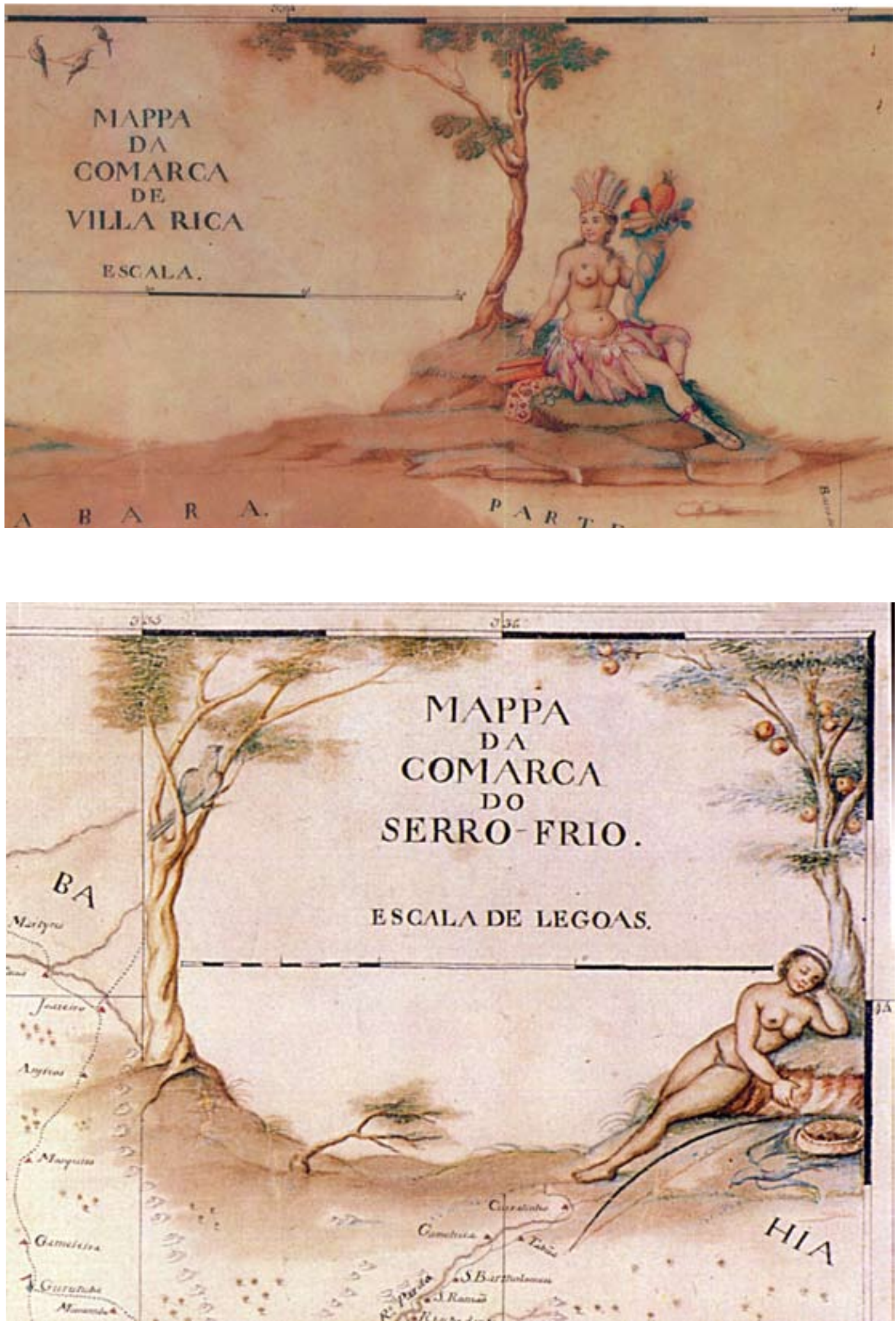

Figura 8 - Detalhe do cartucho do mapa da Comarca de Villa Rica (Figura 4).
Figura 9 - Detalhe do cartucho do mapa da Comarca do Serro-Frio (Figura 5). 


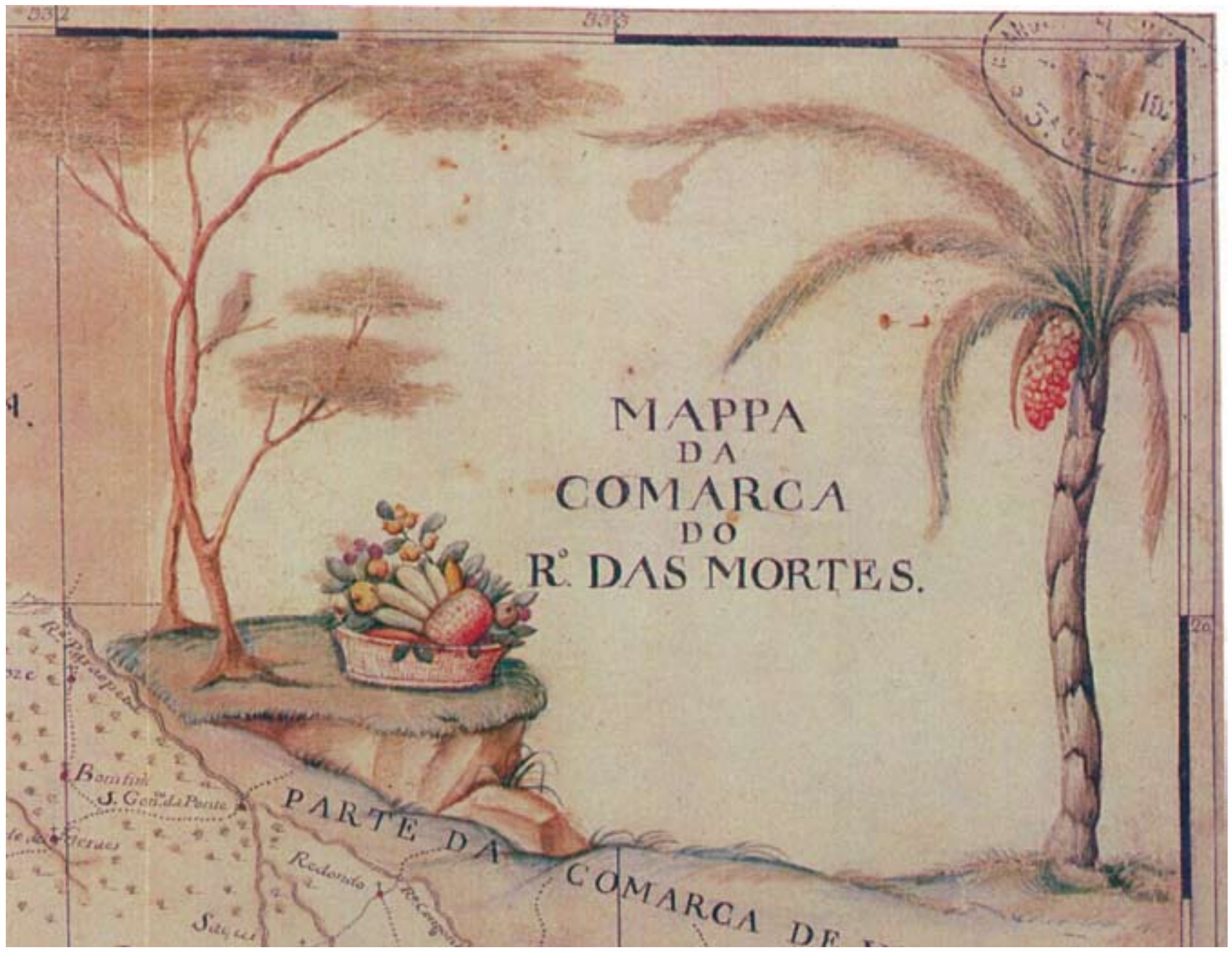

Figura 10 - Detalhe do cartucho do mapa da Comarca do Rio das Mortes (Figura 2).

esquerdo, duas árvores se entrelaçam, tendo duas aves (papagaios) pousadas em seus galhos. Nestas imagens está evidente uma imagem romântica do índio, e uma visão pastoril da natureza, típicas do espaço americano entre os naturalistas da época. Mas, não só. Percebe-se que, através das iluminuras, o artista hierarquiza as diferentes comarcas a partir do nível de riqueza que cada uma ostenta. Assim, não por acaso, a figura que segura a cornucópia de frutas e vestida de forma mais rica está associada à Comarca de Vila Rica, considerada a mais opulenta de todas, o centro de produção aurífera e também da vida administrativa da capitania. Seguem-lhe a Comarca do Rio das Mortes, com o cesto de frutas (mas não a cornucópia), e a do Serro do Frio, área produtora dos diamantes. Vila Rica e Rio das Mortes eram as regiões onde, por essa época, de forma mais efetiva, sedimentara-se uma civilização urbana mais próxima dos moldes europeus, sob a égide de portugueses e paulistas. A Comarca de Sabará, 
apesar de opulenta - como se observa pelas tábuas de rendimentos apresentadas nas Memórias -, é dominada pelo sertão do São Francisco, área ainda inóspita; e, por isso, o autor adorna o mapa da região com um índio em posição de combate.

Mas a quem se destina essa riqueza? A quem pertencem os frutos da terra? Por um lado, o ato de presentear os governadores com as Memórias e as cartas geográficas indicava que, de direito, os frutos da terra pertenciam à Coroa portuguesa e esses documentos instrumentalizavam o seu uso pelas autoridades constituídas. Nesse aspecto, tanto as memórias quanto os mapas reforçam a noção de pátria não só enquanto lugar de eleição do autor, mas enquanto o império sob a égide da monarquia portuguesa. Por outro lado, o fato de ter também disponibilizado o documento a Tiradentes indica que Rocha estava ciente de que haveria outras formas de apropriação dessas riquezas, dessa feita de caráter sedicioso, o que sugere, como apontaram as autoridades nos Autos da Devassa, que ele estivesse mesmo envolvido no movimento. A sentença contra Tiradentes afirma que era clara a intenção dos inconfidentes de se apropriarem das riquezas da capitania e de lançarem mão de um discurso que denunciava a injustiça de seu acúmulo em mãos da Coroa portuguesa. A sentença também afirma que José Joaquim da Rocha estava ciente dessa intenção, pois nela consta que Tiradentes havia falado "em particular a muitos cuja fidelidade pretendeu corromper, principiando por expor-thes as riquezas daquela capitania que podia ser um império florescente, como foi a Antônio da Pestana Fonseca, a José Joaquim da Rocha."74.

As iluminuras dos mapas de Rocha impressionam pela beleza e pela qualidade com que adornam sua cartografia; e, a partir de sua confrontação com as Memórias do autor e com as idéias que circulavam pela capitania, sugerem instigantes formas de interpretá-las. O Mapa da Comarca de Sabará apresenta uma cena em que, de um lado, meio escondido por uma palmeira, um índio em posição de combate impõe um arco e lança uma flecha. A arma está apontada para um plácido e distraído cartógrafo (provavelmente o próprio autor) que, do outro lado da imagem, vestido garbosamente em seu uniforme militar, totalmente concentrado, traça um mapa com seu compasso (Figura 11). De início, lendo a descrição dessa imagem, poderíamos pensar que quem se debruça sobre o mapa é imediatamente despertado pelo sentimento de perigo iminente, pois o cartógrafo inocente é ameaçado pelo índio selvagem. Mas não é assim: de forma inversa, placidez é o que emana da cena. O alheamento do cartógrafo, o fato do observador não ser inundado pelo medo do iminente, mas tranquilizado pela cena pastoril, revela o domínio de uma cultura civilizada frente a outra mais primitiva e selvagem. Simboliza o domínio da cultura ilustrada - à qual não só o cartógrafo estava bem afeito, mas também a elite jovem, oriunda de Coimbra, que se juntou aos rebeldes inconfidentes - sobre o indígena e a natureza brasileira, que José Joaquim da Rocha representa com seu vigor e suas riquezas.

Cartografar um território não é pois uma operação neutra, cuja objetividade estaria assegurada pelo uso de técnicas as mais aperfeiçoadas. Um
74. Cf. Governo de Minas (v 7, 1982, p. 205) 


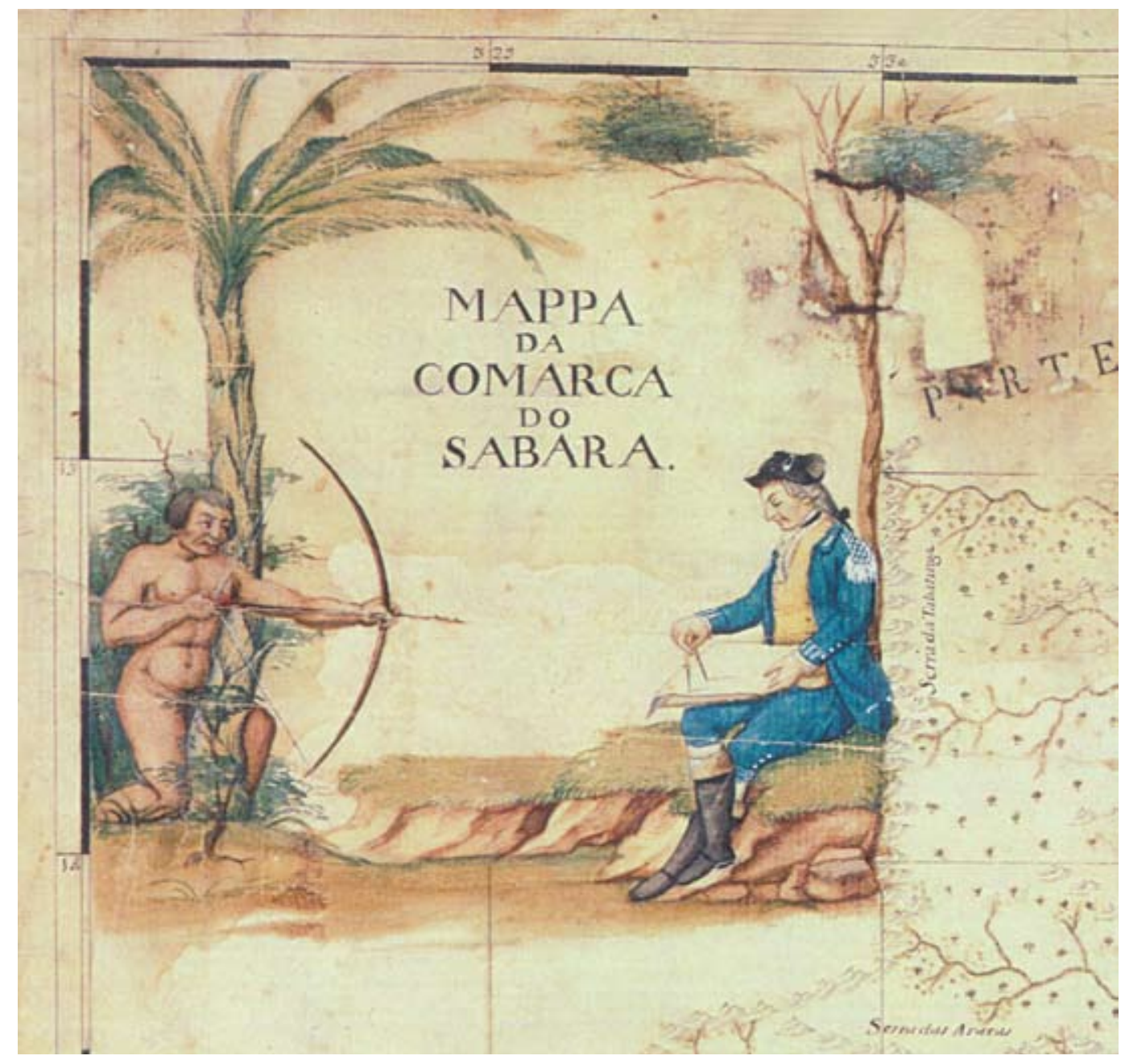

Figura 11 - Detalhe do cartucho do mapa da Comarca do Sabará (Figura 3).

75. Cf. Luciano Raposo de A. Figueiredo e Oswaldo Munteal (1993, p. 26-27). mapa é sempre uma representação de um território, o que implica em vários filtros a separar o real e a coisa representada. Como alertavam os filósofos iluministas, o estudo da natureza, com suas formas de representação geográfica da terra, podia adquirir uma dimensão política. Para o abade Raynal, por exemplo, "a natureza da América é revolucionária"75. Para ele, a relação estabelecida, no continente americano, entre a natureza, o espaço do novo mundo e o homem apresentava uma conexão de causa e efeito que poderia explicar a gênese da Revolução Americana. A partir dessa afirmação de Raynal - cuja leitura era de amplo conhecimento dos inconfidentes -, pode-se perceber que a apropriação dos mapas de Rocha pelo movimento sedicioso de 1789 imprimia novas dimensões à carta; e o caráter unitário da capitania e suas riquezas adquiria novos significados.

Nesse momento, uma leitura paradisíaca da natureza brasileira e, em particular, da mineira, era suplantada por outra, caracterizada por uma visão mais 
racional do espaço. No caso da cartografia, a relação entre o território e as suas formas de representação passara a ser mediada pelo primado da matemática e da geometria - e os mapas de José Joaquim da Rocha ilustraram bem esse processo. Mas não só. Reunindo as questões colocadas pelas Memórias, por sua cartografia e mesmo pelas iluminuras que a ilustram, percebe-se que, aos olhos de José Joaquim da Rocha (como, mais tarde, aos olhos dos demais inconfidentes), o espaço da capitania configurava-se enquanto uma entidade geográfica singular. Podia ser um espaço de exaltação das autoridades portuguesas, desde que, numa lógica clientelista de Antigo Regime, seus frutos fossem também repartidos entre aqueles que se punham a seu serviço. Mas também podia ser um espaço de ruptura e de transformação - e, neste sentido, as reconfigurações da entidade geográfica da capitania podiam adquirir uma dimensão revolucionária e refletir as ameaças aos laços de dependência que ligavam ao reino a antiga conquista portuguesa.

Rebeldes e vassalos?

Não se pretende aqui afirmar que as questões suscitadas pelos inconfidentes - e em particular por José Joaquim da Rocha, em 1789, caso ele tenha estado realmente envolvido no movimento - já se encontravam presentes nos mapas de 1778 e nas Memórias, cuja primeira versão precede o levante em pelo menos onze anos. Nem se pretende analisar e desvendar o discurso contido nas Memórias e em sua produção cartográfica a partir do seu envolvimento no levante, ou vice-versa. Tal procedimento significaria entender esses acontecimentos - separados por cerca de uma década, durante os quais o espírito do autor muito se modificou, e a situação da capitania também passou por transformações como um novelo que se desenrola de forma linear, encadeando inequívocamente os fatos e dotando-os de um significado único. Porém, acredito que eles contêm em si elementos em comum que não um espírito revolucionário, ou nativista, ou pré-emancipatório, pois, como já foi mencionado, o que guia, em primeiro lugar, a produção das Memórias e dos mapas é o serviço à Coroa e a instrumentalização de seus agentes, em busca de ganhos simbólicos e/ou pecuniários pelo autor.

Assim, compreender as ações de José Joaquim da Rocha (tanto na confecção das Memórias quanto dos mapas) e sua possível participação na Inconfidência Mineira - as primeiras com o nítido objetivo de servir às autoridades e a última percebida como ato de sedição - só é possível quando nos distanciamos de interpretações que se solidificaram na historiografia. Durante muito tempo, os estudos salientaram o caráter revolucionário do movimento ${ }^{76} \mathrm{e}$, mais recentemente, na corrente inversa, apontaram o aspecto tradicional do discurso dos inconfidentes ${ }^{77}$. Mas, como poderiam conviver na mesma pessoa, como no caso de José Joaquim da Rocha, o súdito fiel e o rebelde sedicioso? Seria apenas uma
76. Ver Luciano Raposo de Almeida Figueiredo (1996).

77. Ver João Pinto Furtado (2002); e, também, Luís Carlos Villalta (1999); e, ainda, Joaci Pereira Furtado (2006). 
78. Ver Kenneth Maxwell (1978).

79. Ver Idem; e Júnia F. Furtado (1993-1994).

80. Refiro-me, mais especificamente, à nova política orquestrada (sob o cetro de Dona Maria I) por Martinho de Mello e Castro, política essa que, no caso das Minas Gerais, consubstanciou-se com clareza nas Instruções trazidas pelo Visconde de Barbacena.

81. Ver António Manuel Hespanha e Ângela Barreto Xavier (1993).

82. Ver Júnia Ferreira Furtado (1999).

83. Cf. António Manuel Hespanha e Ângela Barreto Xavier (1993, p. 381). questão de intervalo de tempo? Poderia ser explicado apenas pelas mudanças conjunturais ocorridas na capitania?

Sim, parte da resposta pode ser encontrada nas transformações que foram operadas na política da Coroa, e seus impactos na capitania de Minas Gerais, no que diz respeito a suas diversas oscilações conjunturais ${ }^{78}$. Por isso, há muito venho conclamando que não se pode compreender o movimento de 1789 sem analisar especificamente a sua conjuntura, "o que significa reavaliar as relações que se estabeleceram, de um lado, entre a Metrópole e a Colônia e, de outro, entre o aparelho estatal que se montou nas Minas e a população local", em suas diversas temporalidades e oscilações ${ }^{79}$. E que, em fins do século XVIII, a delicada estratégia política que unia os distantes pontos do império passava por uma vigorosa transformação. Na ocasião, os súditos de além-mar da antiga conquista portuguesa na América resistiam a tentativas de recolonização, de cunho ortodoxo, atentadas pela $\mathrm{Coroa}^{80}$. Ainda que sutis, as diferenças entre o primeiro manuscrito da Geografia Histórica - que José Joaquim da Rocha presenteia a Dom Rodrigo de Sousa Coutinho, provavelmente em 1780 - e o texto da Memória Histórica - terminado às vésperas da Inconfidência Mineira, em 1788 - suscitam interessantes considerações e revelam algumas mudanças no estado de espírito do autor e nas particularidades da atuação de cada governador em sintonia com as ordens emanadas da Coroa.

Dessa maneira, não se configura como surpresa, que o único governador cujos feitos não são exaltados na última Memória, a de 1788, seja Luís da Cunha Meneses. Nesse caso, a linguagem insípida e fria de José Joaquim da Rocha refletia a frustração de alguém cujos esforços em busca de promoção e honra não foram satisfeitos. Seu esforço de dedicar a Luís da Cunha Meneses a Descrição Geográfica da Capitania de Minas Gerais, em 1783, não rendera os frutos esperados. Apesar de the dedicar seu serviço e de presenteá-lo com ele, o governador não retribuiu com as promoções esperadas tal feito. E, dessa forma, rompera com a lógica da Economia do Dom, que inseria os homens da época nas cadeias formais e informais de reprodução do poder ${ }^{81}$. Na capitania das Minas Gerais, como extensão do reino, também se previa que "toda oferenda esperava sua recompensa"82, o que determinava "a obrigatoriedade de concessão de mercês aos mais amigos", na forma de obtenção de favores ou cargos junto à Corte. Tais fatos "eram situações sociais quotidianas e corporificavam a natureza mesma das estruturas sociais, sendo portanto vistas como a norma" 83 .

Rocha, em carta dirigida ao ministro Martinho de Melo e Castro, revelou sua insatisfação por não ter tido seu esforço recompensado e, ao mesmo tempo em que expressava seu descontentamento pela demora na concessão de alguma mercê, pedia ao ministro que o recomendasse a Luis da Cunha Meneses e a quem viesse sucedê-lo. Dizia:

"Nunca fui contemplado senão para atropelar riscos, expondo muitas vezes a vida a ser devorada pelas feras na penetração dos densíssimos sertões, sem mais interesse que a utili- 
dade do serviço da Soberana; e por isso indigente, sem amparo, nem estabilidade para poder passar o resto dos anos como homem de bem" ${ }^{\prime 4}$.

Descontente por Luis da Cunha Meneses não ter retribuído e recompensado o serviço realizado, Rocha inverte a lógica que ele mesmo imprimira aos textos das Memórias para, desta feita, ao invés de glorificar o governador que saía, detratá-lo de maneira sutil, mas facilmente percebida a um leitor da época. Na última versão do texto, ele não desfia o rosário de feitos de Luis da Cunha Meneses e limita-se a informar secamente sua posse. Para referir-se a ele, nem ao menos utiliza as formas mais dignas de tratamento - Dom ou Ilustríssimo -, o que seria esperado de acordo com as regras protocolares de alguém que devia obediência e respeito a essa autoridade. Tais fórmulas de tratamento foram utilizadas por ele sempre que se referira aos demais governadores ${ }^{85}$. Em breves linhas, informou apenas que "deu esse governador [Exmo. Dom Rodrigo José de Meneses] posse a Luis da Cunha Meneses, que a tomou em 10 de outubro de 1783, na igreja matriz de Nossa Senhora do Pilar de Ouro Preto, presente a Câmara"86. Nessa insatisfação, ele não estava só. Kenneth Maxwell destaca como, em grande parte, a Inconfidência Mineira foi tramada por uma plutocracia local descontente por ver negadas muitas de suas pretensões individuais ou ter sido ferida em seus interesses mais imediatos por oscilações na política encetada pela Coroa para a região ${ }^{87}$.

Outra parte da resposta a tais questões deve ser encontrada na percepção de que, dos dois lados do Atlântico, desde o início do século, consolidava-se a noção de que o papel do Brasil (particularmente as Minas, com a descoberta das riquezas minerais) se reconfigurava no conjunto do Império, pressionando por novos rearranjos da ordem política ${ }^{88}$. Em todos os momentos - o da produção das Memórias e dos mapas; o da Inconfidência; e o que une essas ações aparentemente díspares e contraditórias tão distantes no tempo -, o que José Joaquim da Rocha (como os demais inconfidentes) almejava era a inserção das Minas Gerais na balança do império, sob novas formas, justificadas pela centralidade que a capitania adquirira no século XVIII. Dessa forma, pode-se entender a confecção das Memórias e das cartas geográficas para além seu significado laudatório; e a deflagração da Inconfidência Mineira não apenas como um ato de rebeldia. $\bigcirc$ movimento não era resultante tão somente (como a historiografia mais recente já tem salientado) do desejo de restauração de um passado ideal perdido ${ }^{89}$, mas da intenção de reinserção das Minas, e por extensão do Brasil, em termos mais favoráveis na balança política do império. Isso tanto podia significar reinserir-se sob outras bases, mais favoráveis, no seio do espectro da monarquia portuguesa, quanto, inversamente, a ruptura política, tal qual ocorrera com as antigas treze colônias da América do Norte.

Não se pode deixar de atentar que a Inconfidência é percebida como um ato sedicioso por seus contemporâneos (especialmente pela Coroa, e inclusive pelos próprios participantes, que buscaram tramar tudo em segredo), pois iria efetivamente subverter a ordem política estabelecida. Nisso reside seu conteúdo
84. Cf. Governo de Minas (v. 5, 1982, p. 48-49); apud Maria Efigênia Lage de Resende (1995, p. 44).

85. Cf. Júnia Ferreira Furtado (1999, p. 63).

86. Cf. José Joaquim da Rocha (1995, p. 159).

87. Ver Kenneth Maxwell (1978).

88. Ver Júnia F. Furtado (2006).

89. Ver João Pinto Furtado (2002); Luís Carlos Villalta (1999); e, ainda, Joaci Pereira Furtado (2006). 
90. Governo de Minas (v.1, 1981, p. 104).

91. Idem, ibidem.

92. No reino português, sob as bases da Segunda Escolástica - e principalmente após a Restauração -, à legitimidade do direito divino dos reis juntou-se a idéia da necessidade de legitimação também a partir de um pacto social com os súditos.

93. Cf. José Joaquim da Rocha (1995, p. 159) transformador. Tal se configura com clareza em um dos diálogos travado por Tiradentes. Ao proferir um de seus discursos em prol do levante, "a isto disse o tal moço de Congonhas [Claro José da Mota]: 'Vosmecê fala assim em levante? Se fosse em Portugal, Deus nos livre que tal se soubesse'" 90. Claro José da Mota deixa evidente que se tratava de um ato de sublevação, mas a resposta de Tiradentes aponta para outros significados do levante, replicando, cheio de paixão: "Não diga levantar é restaurar"91. Tiradentes salienta, em sua réplica, que o propósito dos inconfidentes, além do retorno a um passado perdido, situava-se na lógica da idéia de pacto social como uma das bases legitimadoras do poder régio92. É só nessa dupla dimensão que o súdito fiel e o ardoroso inconfidente podem ser entendidos não como contraditórios, mas como as duas faces de uma mesma moeda, opostas apenas aparentemente. Na Inconfidência, o que se buscava era, ao mesmo tempo, um ato não só de restauração de uma ordem perdida, de reparação de injustiças cometidas, de reequilíbrio das porções geográficas do império sob novas bases hierárquicas, mas nele também trazia embutido o novo, e almejava transformar o estabelecido. Assim, tanto as Memórias e mapas de José Joaquim da Rocha quanto a sua possível participação na Inconfidência podem ser lidas numa dupla chave: podiam ter uma dimensão conservadora; e, ainda, adquirir um significado revolucionário. Mas não é a Inconfidência que dá inteligibilidade às Memórias e aos mapas, pois, lidos assim, iá conteriam em si um germe da rebeldia, o que não era verdade. Mas é à luz da Inconfidência Mineira que se permite perceber que a noção de recentralização do império nas Minas podia adquirir, em ambos os momentos e ao mesmo tempo, tanto uma vertente conservadora (por meio do reforço à autoridade local, no caso os governadores, e por conseguinte da Coroa) como uma vertente transformadora (o ato reorientação política, na forma de uma ruptura e de sedição).

Nessa perspectiva, é que se torna clara, então, por que as primeiras palavras da Memória de 1788, dirigidas ao governador recém-chegado, o visconde de Barbacena, eram todas de louvor. Para Rocha, o "llustríssimo e Excelentíssimo Visconde de Barbacena [...] nas suas primeiras ações se tem demonstrado o governador perfeito, imprimindo nelas o caráter das futuras, que por dilatados anos, há de permitir Deus, sirvam de admiração aos seus sucessores, para o seu governo, de origem das felicidades e para o seu nome de imortal glória"93. E, naquele mesmo ano, José Joaquim da Rocha confabulava com os inconfidentes e, com seus mapas de população e suas cartas geográficas - que assim adquiriam uma nova dimensão e novos significados -, instrumentalizava os planos sediciosos. Reunindo as questões colocadas pelas Memórias, por sua cartografia e mesmo pelas iluminuras que ilustram seus mapas, percebe-se que, aos olhos de José Joaquim da Rocha (como, mais tarde, aos olhos dos demais inconfidentes), o espaço da capitania se configurava enquanto uma entidade geográfica singular. Podia ser um espaço de exaltação das autoridades portuguesas, desde que, numa lógica clientelista de Antigo Regime, seus frutos fossem também repartidos entre aqueles que se punham a seu serviço; e, também, um espaço de ruptura e transformação - e, neste sentido, as reconfigurações da 
entidade geográfica da capitania podiam adquirir uma dimensão revolucionária e refletir as ameaças aos laços de dependência que ligavam a antiga conquista portuguesa ao reino.

\section{REFERÊNCIAS}

ABREU, J. R. Historiologia Médica, fundada e estabelecida nos princípios de George Ernesto Stahl, 1. Lisboa: Oficina de Antônio de Sousa da Silva, 1733.

ALCIDES, S. Estes penhascos: Cláudio Manuel da Costa e a paisagem das Minas (1753-1773). São Paulo: Hucitec, 2003.

ALMEIDA, A. F. de. A formação do espaço brasileiro e o projecto do Novo Atlas da América Portuguesa (1713 -1748). Lisboa: Comissão Nacional para as Comemorações dos Descobrimentos Portugueses, 2001.

ÁVILA, Cristina; GOMES, Maria do Carmo. A representação espacial das Minas Gerais no século XVIII: relações entre a cartografia e a arte. Barroco, arquitetura e artes plásticas, Ouro Preto, v.15, p. 441-446, 1990-1992.

BLUTEAU, Rafael. Dicionário da língua portuguesa. Ampl. Antônio de Morais. Lisboa: Oficina de Thadeo Ferreira, 1739.

BORGES, Maria Eliza Linhares. A hermenêutica cartográfica em uma sociedade miscigenada. In: PAIVA, Eduardo F.; ANASTASIA, Carla M. J. (Orgs.). O Trabalbo mestiço: maneiras de pensar e formas de viver, séc. XVI a XIX. São Paulo: Annablume, 2002. p.105-122

BRUCKNER, M. The geographic revolution in early America: maps, literacy and national identity. Virginia: Omohundro Institute of Early American History and Culture, 2006.

BUENO, B. P. S. Desenho e desígnio: o Brasil dos engenheiros militares (1500-1822). 2001. Tese (Doutorado em Estruturas Ambientais Urbanas) - Faculdade de Arquitetura e Urbanismo, Universidade de São Paulo, São Paulo, 2001 (versão revisada em 2003).

O Engenheiro Artista: as aquarelas e as tintas nos mapas do novo mundo. In: FURTADO, Júnia Ferreira (Org.). Formas, sons, cores e movimento na modernidade Atlântica: Europa, Américas e África. São Paulo: Annablume, 2008.

CANAVARRAS, O. O poder metropolitano em Cuiabá (1727-1752). Cuiabá: Editora da Universidade Federal de Mato Grosso, 2004.

COSENTINO, Francisco Carlos C. Governadores Gerais do Estado do Brasil (séculos XVI e $X V I I)$ : ofício, regimentos, governação e trajetórias, 2005. Tese (Doutorado em História) Universidade Federal Fluminense, Niterói, 2005.

COSTA, Antônio Gilberto et al. (Org.). Os mapas de José Joaquim da Rocha. In: Cartografia da conquista das minas. Lisboa: Kappa; Belo Horizonte: Editora da UFMG, 2004.

CUNHA, Luís da. Carta de Instruções a Marco Antônio de Azevedo Coutinho. In: SILVA, Abílio Diniz (Org.). Instruções políticas. Lisboa: Comissão Nacional para as Comemorações dos Descobrimentos Portugueses, 2001. p. 371. 
FIGUEIREDO, Luciano Raposo de Almeida. Painel Histórico. In: PROENÇA FILHO, D. (Org.). $A$ poesia dos Inconfidentes: poesia completa de Cláudio Manoel da Costa, Tomás Antônio Gonzaga e Alvarenga Peixoto. Rio de Janeiro: Nova Aguiar, 1996.

; CAMPOS, Maria Verônica (Coord.). Códice Costa Matoso. Belo Horizonte: Fundação João Pinheiro, 1999.

; MUNTEAL, O. Prefácio: a propósito do abade Raynal. In: RAYNAL, G.T. F. A Revolução da América. Rio de Janeiro: Arquivo Nacional, 1993. p. 26-27.

FONSECA, Cláudia D. Des terres aux villes de l'or. Pouvoirs et territoires urbains au Minas Gerais (Brésil, XVIIIe siècle). Paris: Centre Culturel Calouste Gulbenkian, 2003a.

Funções, hierarquias e privilégios urbanos: a concessão dos títulos de vila e cidade na capitania de Minas Gerais. Varia Historia, Belo Horizonte, v. 29, p.39-51, 2003 b.

FURTADO, Joaci Pereira. O falso manifesto da revolução que nunca houve. Nossa História, Rio de Janeiro, v. 3, n. 31, p. 80-83, maio 2006.

FURTADO, João Pinto. O manto de Penélope: história, mito e memória da Inconfidência Mineira de 1788-9. São Paulo: Companhia das Letras, 2002.

FURTADO, Júnia F. O outro lado da Inconfidência Mineira: pacto colonial e elites locais. LPH-Revista de História, Ouro Preto, v. 4, p.70-91, 1993-1994.

O Livro da Capa Verde: a vida no Distrito Diamantino no período Real Extração. São Paulo: Annablume, 1996.

Toda oferenda espera sua recompensa. In: Homens de Negócio: a interiorização da metrópole e do comércio nas Minas setecentistas. São Paulo: Hucitec, 1999. p.46-57.

. José Rodrigues Abreu e a geografia imaginária emboaba da conquista do ouro. In: BICALHO, M. F.; FERLINI, V. L. A. Modos de Governar: idéias e práticas políticas no Império Português (séc. XVI a XIX). São Paulo: Alameda, 2005. p. 277-295.

Sedição, heresia e rebelião nos trópicos: a biblioteca do naturalista José Vieira Couto. In: DUTRA, E. de F.; MOLLIER, J. Y. (Org.). Política, nação e edição: o lugar dos impressos na construção da vida política Brasil, Europa e Américas nos Séculos XVIII-XX. São Paulo: Annablume, 2006.

(Org.). Formas, sons, cores e movimento na modernidade Atlântica: Europa, Américas e África. São Paulo: Annablume, 2008.

GOVERNO DE MINAS. Autos da Devassa da Inconfidência Mineira. Belo Horizonte: Imprensa Oficial do Estado, 1981. Vários volumes.

HESPANHA, A M.; XAVIER, A B. As redes clientelares. In: MATTOSO, J. (Org.). História de Portugal. O antigo regime, 4. Lisboa: Estampa, 1993. p.381-393.

MAXWELL, K. A devassa da devassa. Rio de Janeiro: Paz e Terra, 1978.

MOREL, Marco. Pátrias polissêmicas: República das letras e imprensa na crise do império português na América. In: KURY, Lorelai (Org.). Iluminismo e império no Brasil: O Patriota (1813-1814). Rio de Janeiro: Fiocruz, 2007. 
PROENÇA FILHO, D. (Org). A poesia dos Inconfidentes: poesia completa de Cláudio Manoel da Costa, Tomás Antônio Gonzaga e Alvarenga Peixoto. Rio de Janeiro: Nova Aguiar, 1996.

RESENDE, M. E. L. de. Estudo crítico. In: ROCHA, José Joaquim da. Geografia Histórica da capitania de Minas Gerais. Belo Horizonte: Fundação João Pinheiro, 1995. p. 13-66.

A disputa pela história. Traços inscritos na memorialística histórica mineira dos finais do setecentismo. Varia Historia, Belo Horizonte, n. 20, p. 60-77, março 1999.

ROCHA, José Joaquim da. Geografia Histórica da capitania de Minas Gerais. Coord. Maria Efigênia Lage de Resende. Belo Horizonte: Fundação João Pinheiro, 1995.

ROMEIRO, A.; BOTELHO, A. V. Dicionário histórico das Minas Gerais: período colonial. Belo Horizonte: Autêntica, 2003.

SILVA, Abílio Diniz (Org.). Instruções políticas. Lisboa: Comissão Nacional para as Comemorações dos Descobrimentos Portugueses, 2001.

SOUZA, L. de M. e. Um servidor e dois impérios: Dom José Tomás de Meneses. In: O sol e a sombra: política e administração na América portuguesa do século XVIII. São Paulo: Companhia das Letras, 2006. p. 403-450.

TEIXEIRA, R. do N. (Org.). O Vale do Rio Doce. Rio de Janeiro: Companhia Vale do Rio Doce, 2002.

VILLALTA, L. C. Reformismo ilustrado, censura e práticas de leitura: usos do livro na América portuguesa. 1999. Tese (Doutorado em História) - Faculdade de Filosofia, Letras e Ciências Humanas, Universidade de São Paulo, São Paulo, 1999.

WASHBURN, Wilcomb E. As ilhas Canárias e a questão do meridiano de referência: a busca do rigor na medição da terra. In: CONTENTE, Francisco; BARRETO, Luís Filipe. A abertura do mundo: Estudos de História dos descobrimentos europeus, 1. Lisboa: Presença, 1987. p. 213-220.

Artigo apresentado em 9/2009. Aprovado em 12/2009. 